\title{
Reduced Inhibition of Dentate Granule Cells in a Model of Temporal Lobe Epilepsy
}

\author{
Masayuki Kobayashi and Paul S. Buckmaster \\ Departments of Comparative Medicine and Neurology and Neurological Science, Stanford University School of Medicine, Stanford, California $94305-5342$
}

Patients and models of temporal lobe epilepsy have fewer inhibitory interneurons in the dentate gyrus than controls, but it is unclear whether granule cell inhibition is reduced. We report the loss of GABAergic inhibition of granule cells in the temporal dentate gyrus of pilocarpine-induced epileptic rats. In situ hybridization for GAD65 mRNA and immunocytochemistry for parvalbumin and somatostatin confirmed the loss of inhibitory interneurons. In epileptic rats, granule cells had prolonged EPSPs, and they discharged more action potentials than controls. Although the conductances of evoked IPSPs recorded in normal ACSF were not significantly reduced and paired-pulse responses showed enhanced inhibition of granule cells from epileptic rats, more direct measures of granule cell inhibition revealed significant deficiencies. In granule cells from epileptic rats, evoked monosynaptic IPSP conductances were $<40 \%$ of controls, and the frequency of $\mathrm{GABA}_{\mathrm{A}}$ receptor-mediated spontaneous and miniature IPSCs (mIPSCs) was $<50 \%$ of controls. Within 3-7 d after pilocarpine-induced status epilepticus, miniature IPSC frequency had decreased, and it remained low, without functional evidence of compensatory synaptogenesis by GABAergic axons in chronically epileptic rats. Both parvalbumin- and somatostatin-immunoreactive interneuron numbers and the frequency of both fast- and slow-rising $\mathrm{GABA}_{\mathrm{A}}$ receptor-mediated mIPSCs were reduced, suggesting that loss of inhibitory synaptic input to granule cells occurred at both proximal/somatic and distal/dendritic sites. Reduced granule cell inhibition in the temporal dentate gyrus preceded the onset of spontaneous recurrent seizures by days to weeks, so it may contribute, but is insufficient, to cause epilepsy.

Key words: dentate gyrus; hippocampus; GABA; interneurons; IPSPs; IPSCs; GAD; somatostatin; parvalbumin; mossy fiber sprouting; basal dendrites; paired pulse

\section{Introduction}

Temporal lobe epilepsy is the most common type of epilepsy in adults (Engel et al., 1997). Patients with temporal lobe epilepsy display specific patterns of neuron loss, and the most consistent loss occurs in the hilus of the dentate gyrus (Margerison and Corsellis, 1966). Some of the missing cells are interneurons (de Lanerolle et al., 1989; Mathern et al., 1995a; Wittner et al., 2001). Whether granule cells, the principal neurons of the dentate gyrus, are less inhibited is an important but unresolved issue.

Despite the loss of interneurons, many previous studies that evaluated tissue from patients or models of temporal lobe epilepsy found evidence of normal or enhanced granule cell inhibition. Surviving GABAergic interneurons have been reported to sprout axon collaterals and form new inhibitory synapses with granule cells (Babb et al., 1989; Davenport et al., 1990; Mathern et al., 1995a, 1997; Andre et al., 2001; Wittner et al., 2001). Unit and field potential recordings provide evidence of robust inhibition in tissue from patients with temporal lobe epilepsy (Isokawa-

\footnotetext{
Received Sept. 11, 2002; revised Dec. 18, 2002; accepted Dec. 20, 2002.

This work was supported by the National Institutes of Health/National Institute of Neurological Disorders and Stroke (NS39110 and NS40276). M.K. is the recipient of a fellowship from the Uehara Memorial Foundation. P.S.B. is the recipient of a Burroughs Wellcome Fund Career Award. We thank Dr. J. Huguenard for software and advice on IPSC data analysis, Dr. D. Prince for suggestions on this manuscript, Drs. A. Tobin and N. Tillakaratne for GAD CDNAs, and Dr. X. Wen for assistance with in situ hybridization.

Correspondence should be addressed to Paul Buckmaster, Department of Comparative Medicine, Stanford University School of Medicine, 300 Pasteur Drive, R321 Edwards Building, Stanford, CA 94305-5342. E-mail: psb@stanford.edu.

M. Kobayashi's present address: Department of Oral Physiology, Osaka University Graduate School of Dentistry, Yamadaoka 1-8, Suita, 0saka 565-0871, Japan.

Copyright $\odot 2003$ Society for Neuroscience $\quad 0270-6474 / 03 / 232440-13 \$ 15.00 / 0$
}

Akesson et al., 1989; Uruno et al., 1995; Colder et al., 1996; Wilson et al., 1998). Paired-pulse inhibition of granule cells is enhanced in models of temporal lobe epilepsy (Tuff et al., 1983; Haas et al., 1996; Buckmaster and Dudek, 1997). GABA receptor density is greater in acutely isolated granule cells from epileptic rats compared with controls (Gibbs et al., 1997). Granule cells express more $\mathrm{GABA}_{\mathrm{A}}$ receptors per synapse in kindled animals compared with controls (Otis et al., 1994; Nusser et al., 1998). Some intracellular and whole-cell patch-clamp studies of granule cells from patients and models of temporal lobe epilepsy report relatively normal inhibitory postsynaptic responses (Franck et al., 1995; Buhl et al., 1996; Isokawa, 1996; Buckmaster and Dudek, 1999; Okazaki et al., 1999), but others found reduced IPSPs (Williamson et al., 1995, 1999).

To address this unsettled issue we used multiple approaches to evaluate the inhibition of granule cells at different stages of epileptogenesis in the pilocarpine-treated rat model of temporal lobe epilepsy. We compared electrophysiological results with anatomical measures of interneuron loss in adjacent slices. We examined the dentate gyrus in the temporal pole of the hippocampus, which is homologous to the part of the hippocampus that is resected from patients with temporal lobe epilepsy and is the region in which neuron loss in patients and models is most severe (Babb et al., 1984; Masukawa et al., 1996; Buckmaster and Dudek, 1997). We found reduced inhibition of granule cells in epileptic rats and asked the following questions. Does the loss of inhibition precede or follow the onset of spontaneous, recurrent seizures? Is there functional evidence that surviving inhibitory interneurons form additional, compensatory synapses in chronically epileptic 
animals? Where on the granule cells (soma, dendrites, or both) are inhibitory synapses lost?

\section{Materials and Methods}

Animal treatment. We used the pilocarpine-treated rat model of temporal lobe epilepsy because it replicates the cell type-specific pattern of neuron loss and axon reorganization found in many patients with temporal lobe epilepsy (Turski et al., 1983; Mello et al., 1993). It also is similar to a common clinical history of patients with temporal lobe epilepsy (Mathern et al., 1995b), in that a brain injury precedes a seizure-free latent period before spontaneous, recurrent seizures begin. All experiments were performed in accordance with the National Institutes of Health Guide for the Care and Use of Laboratory Animals and approved by the Stanford University Institutional Animal Care and Use Committee.

Sprague Dawley male rats (35-77 d old) were treated with pilocarpine (380 mg/kg, i.p.) $20 \mathrm{~min}$ after atropine methylbromide $(5 \mathrm{mg} / \mathrm{kg}$, i.p.). Approximately $60 \%$ of the treated rats experienced status epilepticus. Diazepam $(10 \mathrm{mg} / \mathrm{kg}$, i.p.) was administered $2-3 \mathrm{hr}$ after onset of status epilepticus and repeated, as needed.

Slice preparation. Animals were deeply anesthetized with pentobarbital (75 mg/kg, i.p.) and decapitated. Tissue blocks including the dentate gyrus were removed rapidly and stored for $3 \mathrm{~min}$ in modified ice-cold artificial CSF (M-ACSF) containing (in $\mathrm{mM}$ ): 230 sucrose, $2.5 \mathrm{KCl}, 10$ $\mathrm{MgSO}_{4}, 1.25 \mathrm{NaH}_{2} \mathrm{PO}_{4}, 26 \mathrm{NaHCO}_{3}, 2.5 \mathrm{CaCl}_{2}$, and 10 D-glucose. Horizontal slices were cut by a microslicer (Lancer series 3000, Vibratome, St. Louis, MO) into $425-\mu \mathrm{m}$-thick sections for sharp intracellular electrode recording and $350-\mu \mathrm{m}$-thick sections for whole-cell patch-clamp recording. Slices were incubated at $32^{\circ} \mathrm{C}$ for $40 \mathrm{~min}$ in a submersion-type holding chamber that contained 50\% M-ACSF and 50\% normal ACSF (ACSF), pH 7.35-7.40. ACSF contained (in mM): $126 \mathrm{NaCl}, 3 \mathrm{KCl}, 2$ $\mathrm{MgSO}_{4}, 1.25 \mathrm{NaH}_{2} \mathrm{PO}_{4}, 26 \mathrm{NaHCO}_{3}, 2.0 \mathrm{CaCl}_{2}$, and 10 D-glucose. After that, slices were placed in ACSF at $32^{\circ} \mathrm{C}$ for $1 \mathrm{hr}$. ACSF was aerated continuously with a mixture of $95 \% \mathrm{O}_{2} / 5 \% \mathrm{CO}_{2}$. Slices were thereafter maintained at room temperature until they were used for recording.

Intracellular recording. We used sharp intracellular electrodes and current clamp in some evoked response experiments of the present study. Although whole-cell patch-clamp recording could have been used to measure IPSP conductance, we chose sharp electrode recordings because they can be compared more directly with most of the relevant published studies that also used sharp electrode recordings, they reduce cell dialysis, and in our hands, they generate more consistent and superior intracellular labeling. In a recording chamber (Fine Science Tools, Foster City, $\mathrm{CA})$, slices were maintained at an interface of humidified $95 \% \mathrm{O}_{2} / 5 \%$ $\mathrm{CO}_{2}$ and ACSF flowing at $1 \mathrm{ml} / \mathrm{min}$ and maintained at $30-32^{\circ} \mathrm{C}$. Recording electrodes were made from quartz (P-2000, Sutter Instruments, Novato, $\mathrm{CA})$ and filled with $2 \%$ biocytin and $1 \mathrm{M}$ potassium acetate (100$180 \mathrm{M} \Omega$ ). Signals were amplified (AxoClamp 2B and CyberAmp 380, Axon Instruments, Foster City, CA), observed on-line, and stored (pCLAMP, Axon Instruments).

IPSPs were recorded in normal ACSF, and monosynaptic IPSPs were recorded in the presence of glutamate receptor antagonists $[50 \mu \mathrm{M}$ 6-cyano-7-nitro-quinoxaline-2,3-dione (CNQX) and $100 \mu \mathrm{M}$ D-2amino-5-phosphonovalerate (D-APV), RBI, Natick, MA]. IPSP reversal potentials were measured by altering the membrane potential with DC current to change the amplitude and polarity of postsynaptic potentials. IPSP amplitude was plotted against the prestimulus membrane potential, and data were fit with a least-squares regression line to estimate the reversal potential. IPSP conductance was calculated by subtracting the input conductance of the cell before stimulation from its conductance during the IPSP (20 and $150 \mathrm{msec}$ after the stimulus artifact). Conductance was the slope of $I-V$ curves, where $I$ was DC holding current and $V$ was membrane potential.

Whole-cell patch-clamp recording. Whole-cell patch-clamp recordings were obtained from granule cells identified with Nomarski optics (40×; Nikon, Tokyo, Japan) and an infrared-sensitive video camera (Hamamatsu Photonics, Hamamatsu City, Japan). Electrical signals were amplified by a patch amplifier (Axopatch 1-D, Axon Instruments) for voltage-clamp recordings and by an intracellular amplifier (AxoClamp 2B, Axon Instruments) for current-clamp recordings. The composition of the pipette solution for voltage-clamp recordings was (in $\mathrm{mM}$ ): 120 cesium methanesulfonate, 20 biocytin, $10 \mathrm{HEPES}, 8 \mathrm{NaCl}, 5 \mathrm{QX}-314,2$ magnesium ATP, 0.3 sodium GTP, and 0.1 BAPTA. The presence of QX-314 and cesium in the pipette solution precluded recording $\mathrm{GABA}_{\mathrm{B}}$ receptor-mediated IPSCs. The pipette solution for whole-cell current-clamp recordings contained (in $\mathrm{mM}$ ): 100 potassium gluconate, 40 HEPES, 20 biocytin, 10 EGTA, $5 \mathrm{MgCl}_{2}$, 2 disodium ATP, and 0.3 sodium GTP. Pipette solutions had a $\mathrm{pH}$ of 7.3 and osmolarity of $300 \mathrm{mOsm}$. The liquid junction potential for voltage-clamp recordings was $7 \mathrm{mV}$, and all voltages were corrected accordingly. Thick-wall borosilicate patch electrodes (4-6 M $\Omega$ ) were pulled on a Flaming-Brown micropipette puller (P-97, Sutter Instruments).

Recordings were obtained at $30-31^{\circ} \mathrm{C}$. Seal resistance was $>5 \mathrm{G} \Omega$, and only data obtained from electrodes with access resistance of 8-17 $\mathrm{M} \Omega$ and $<20 \%$ change during recordings were included in this study. Series resistance was $80 \%$ compensated. Spontaneous (s), miniature (m), and evoked IPSCs were measured near the reversal potential of glutamatergic input $(0 \mathrm{mV})$. For blocking $\mathrm{GABA}_{\mathrm{A}}$ and glutamate receptors, $10 \mu \mathrm{M}$ bicuculline methiodide and $25 \mu \mathrm{M}$ CNQX/50 $\mu \mathrm{M}$ D-APV, respectively, were bath applied. To record mIPSCs, $1 \mu \mathrm{M}$ tetrodotoxin (TTX) was applied in combination with CNQX and D-APV. Paired patch-clamp recordings were obtained from putative basket cells and granule cells. Basket cells were recorded in current-clamp mode, and bridge balance was adjusted during recording. Membrane currents and potentials were low-pass filtered at $1-2 \mathrm{kHz}$ and digitized at $4-8 \mathrm{kHz}$.

Data analysis. Both sIPSCs and mIPSCs were automatically detected by customized software (kindly provided by Dr. J. Huguenard, Stanford University) using the second derivative of the current traces as the trigger (Ulrich and Huguenard, 1996). Threshold values were set at three times the SD of baseline noise amplitude. For every recording we visually checked at least $10 \%$ of the file to verify that the software accurately detected events. More than $95 \%$ of the visually identified events were detected by the software, and false positives accounted for $<1 \%$ of the events detected by the software. Threshold values for sIPSCs recorded in normal ACSF were $5.6 \pm 0.2 \mathrm{pA}$ in epileptic rats $(n=23$ cells $), 4.9 \pm 0.2$ $\mathrm{pA}$ in adult control rats $(n=42$ cells $), 4.8 \pm 0.2 \mathrm{pA}$ in $3-7 \mathrm{~d}$ post-status epilepticus rats $(n=42$ cells $)$, and $4.9 \pm 0.2 \mathrm{pA}$ in young control rats $(n=$ 64 cells). Threshold values for mIPSC recordings were $4.0 \pm 0.1 \mathrm{pA}$ in epileptic rats $(n=20$ cells), $3.6 \pm 0.1 \mathrm{pA}$ in adult control rats $(n=36$ cells), $3.6 \pm 0.1 \mathrm{pA}$ in $3-7 \mathrm{~d}$ post-status epilepticus rats ( $n=34$ cells), and $3.8 \pm 0.2 \mathrm{pA}$ in young control rats $(n=44$ cells $)$. IPSC frequency was measured from continuous recordings that were at least $2 \mathrm{~min}$ long. The distributions of mIPSC rise times were fit with two Gaussians (Origin, Microcal Software Inc., Northampton, MA). To evaluate levels of spontaneous inhibitory synaptic input, the charge transfer of sIPSCs was summed over a period of time by measuring the area between the trace containing sIPSCs and the baseline. All statistical values are presented as mean \pm SEM. Statistical comparisons were performed using a $\chi^{2}$ test, $t$ test, or Spearman Rho test. The level of $p<0.05$ was considered statistically significant.

Anatomy. Immediately after slicing, the first and the last slice prepared were placed in $4 \%$ paraformaldehyde in $0.1 \mathrm{~m}$ phosphate buffer (PB), $\mathrm{pH}$ 7.4 , at $4^{\circ} \mathrm{C}$ for at least $24 \mathrm{hr}$. After fixation, slices were stored in $30 \%$ ethylene glycol and $25 \%$ glycerol in $50 \mathrm{~mm} \mathrm{~PB}$ at $-20^{\circ} \mathrm{C}$ or less. Slices were sectioned with a sliding microtome set at $30 \mu \mathrm{m}$. From each slice, one section was stained with thionin. Others were processed for somatostatin or parvalbumin immunoreactivity or GAD65 mRNA in situ hybridization using previously described protocols and reagents (Buckmaster and Dudek, 1997; Buckmaster and Jongen-Rêlo, 1999). The GAD65 cDNA (kindly provided by Drs. A. Tobin and N. Tillakaratne, University of California at Los Angeles) was $\sim 2.4 \mathrm{~kb}$ and was isolated from a $\lambda$ ZapII library from adult rat hippocampus (Erlander et al., 1991). Neuronal profile counts were measured with a neurolucida system (MicroBrightField, Colchester, VT). A contour was drawn along the borders of the dentate gyrus (see Fig. 1a). The border between the hilus and the $\mathrm{CA} 3$ region was drawn as straight lines from the ends of the granule cell layer to the proximal end of the CA3 pyramidal cell layer. Within the contour, all of the neuron profiles of interest were counted (somatostatin- or parvalbumin-immunoreactive neurons, GAD65 mRNA-positive neurons, or hilar Nissl-stained neurons). Results from 
the first and last slice prepared from an animal were averaged. All of the slices used for electrophysiology were between the two slices prepared for anatomy.

To visualize biocytin-labeled neurons after sharp-electrode recording, slices were fixed, cryoprotected, and sectioned $(60 \mu \mathrm{m})$. Sections were processed using the $\mathrm{ABC}$ method (Vector Laboratories, Burlingame, $\mathrm{CA}$ ) and nickel-intensified diaminobenzidine as the chromogen. All chemicals unless specified were purchased from Sigma (St. Louis, MO).

\section{Results}

Epileptic rats $(n=25)$ experienced pilocarpine-induced status epilepticus when they were $51 \pm 3 \mathrm{~d}$ old. They were videomonitored for seizure activity $40 \mathrm{hr} /$ week. Their first observed spontaneous seizure occurred $26 \pm 3 \mathrm{~d}$ after status epilepticus, and they were used in an experiment $28 \pm 4 \mathrm{~d}$ later. Controls for the epileptic rats included age-matched naive rats $(n=17)$ and pilocarpine-treated rats that did not experience status epilepticus and did not develop epilepsy $(n=21)$. In some experiments, rats ( $n=15$ ) were examined 3-7 d after status epilepticus, before the onset of spontaneous seizures. It is likely that most, if not all, of these rats would have become epileptic, because $>90 \%$ of the 82 rats that we have video-monitored displayed spontaneous, recurrent seizures within 3 months after pilocarpine-induced status epilepticus. The control group for the 3-7 d post-status epilepticus rats included age-matched naive rats $(n=25)$ and pilocarpinetreated rats that did not have status epilepticus $(n=14)$. We found no significant differences in the anatomical or electrophysiological results from naive controls versus pilocarpine-treated controls.

\section{Interneuron loss after status epilepticus}

Patients with temporal lobe epilepsy have fewer interneurons in the dentate gyrus than controls (de Lanerolle et al., 1989; Mathern et al., 1995a; Wittner et al., 2001). Experimental models of temporal lobe epilepsy display similar patterns of interneuron loss (Sloviter, 1991; Obenaus et al., 1993; Schwarzer et al., 1995; Houser and Esclapez, 1996; Buckmaster and Dudek, 1997; Buckmaster and Jongen-Rêlo, 1999; Andre et al., 2001; Gorter et al., 2001). This was true for pilocarpine-treated rats that experienced status epilepticus. Compared with age-matched controls, the number of GAD65 mRNA-positive neuron profiles in the dentate gyrus was reduced to 66 and $71 \%$ in epileptic rats and in 3-7 d post-status epilepticus rats, respectively (Figs. $1 c, d, 2 a$ ). The average number of GAD65 mRNA-positive neuron profiles per dentate gyrus in 3-7 d post-status epilepticus rats $(215 \pm 18 ; n=$ 12) was similar to that of chronically epileptic rats $(200 \pm 11 ; n=$ 24 ), suggesting that virtually all of the interneuron loss occurred by 3-7 d after status epilepticus.

There are many different types of GABAergic interneurons in the dentate gyrus. Somatostatin-immunoreactive interneurons are abundant, and they synapse preferentially with the distal dendrites of granule cells (Leranth et al., 1990; Katona et al., 1999; Buckmaster et al., 2002a). In contrast, parvalbumin-immunoreactive interneurons synapse preferentially at or near the granule cell body (Kosaka et al., 1987). In slices from control rats, somatostatinimmunoreactive profiles accounted for 27\% of the GAD65 mRNApositive profiles in the dentate gyrus, similar to previous stereological results (Buckmaster and Jongen-Rêlo, 1999). In controls, parvalbumin-positive profiles accounted for $8 \%$ of the GAD65 mRNA-positive neuron profiles in the dentate gyrus. After status epilepticus, the average number of both somatostatin- and parvalbumin-immunoreactive interneuron profiles per dentate gyrus was reduced to $46-48 \%$ of controls (Figs. $1 e-h, 2 a$ ).

When using neurochemical markers to identify and count neurons, it is important to determine whether neurons die or just reduce marker expression. Seizure activity can reduce parvalbumin immunoreactivity in surviving interneurons (Scotti et al., 1997), and we could not measure parvalbumin-positive interneuron numbers in 3-7 d post-status epilepticus rats, because somata were not reliably labeled that soon after status epilepticus. In the dentate gyrus, somatostatin-immunoreactive cell bodies are found almost exclusively within the hilus. The number of somatostatin-immunoreactive interneurons was correlated with the number of Nissl-stained hilar neurons in the same slice (Fig. $2 b$ ), suggesting that these interneurons were killed and did not just lose their immunoreactivity. Surviving somatostatinimmunoreactive neurons and their axons in the outer molecular layer were labeled more intensely in epileptic rats compared with controls (Fig. 1e,f), confirming previous results from patients (Mathern et al., 1995a) and models of temporal lobe epilepsy (Wanscher et al., 1990; Schwarzer et al., 1995; Buckmaster and Dudek, 1997). Similarly, the intensity of GAD65 mRNA expression in somata increased in epileptic rats (Figs. $1 c, d$ ) (Feldblum et al., 1990; Houser and Esclapez, 1996).

In patients with temporal lobe epilepsy, neuron loss in the dentate gyrus is most severe in the temporal end of the hippocampus (Babb et al., 1984; Masukawa et al., 1996). Similarly, in kainate-treated epileptic rats, interneuron loss is most severe in the temporal dentate gyrus (Buckmaster and Jongen-Rêlo, 1999), and frequently the temporal dentate gyrus is the only dentate region in which the number of parvalbumin-immunoreactive interneurons is reduced (Buckmaster and Dudek, 1997). We found similar results in pilocarpine-induced epileptic rats. All of the slices examined in the present study were from the temporal part of the hippocampus, but some slices were more temporal than others. GAD65 mRNA-positive neuron loss was more severe in the ventral (most temporal) slices than in the dorsal slices. The number of GAD65 mRNA-positive neuron profiles was reduced to $58 \%$ in ventral slices and to $70 \%$ of controls in dorsal slices.

\section{Granule cells are hyperexcitable in epileptic rats}

Perforant path fibers in the outer two-thirds of the molecular layer provide the predominant excitatory synaptic input to granule cells. The outer molecular layer was stimulated with a bipolar electrode (25 $\mu \mathrm{m}$ diameter, insulated stainless steel wires) placed 100-300 $\mu \mathrm{m}$ off-center from the impaled cell. Stimulus intensity was gradually increased and set to evoke the maximal amplitude IPSP at a $150 \mathrm{msec}$ latency $(0.2 \mathrm{msec}, 0.1 \mathrm{~Hz})$. Stimulation of the outer molecular layer revealed hyperexcitability of granule cells in slices from epileptic rats. The maximum number of action potentials discharged per stimulus was higher in epileptic rats ( $1.4 \pm 0.1 ; n=84$ cells) compared with controls $(0.7 \pm 0.1 ; n=$ 74 cells; $p<0.0001$; unpaired $t$ test) (Fig. $3 a-c)$. At stimulation intensities below spike threshold, prolonged depolarizations were evident in epileptic (Fig. 3b2) but not control rats. Resting membrane potential and input resistance were similar in epileptic and control groups (Table 1) (Buckmaster and Dudek, 1999; Williamson et al., 1999). Granule cells from control or epileptic rats responded to current step injection with a train of action potentials and never with a burst (Fig. $3 d$ ). These findings suggest that changes in synaptic transmission, rather than changes in intrinsic firing properties, underlie the hyperexcitability of granule cells in epileptic rats. Granule cell hyperexcitability to orthodromic stimulation has been found in tissue from patients (Isokawa and Levesque, 1991; Franck et al., 1995; Williamson et al., 1995; Isokawa, 1996; Masukawa et al., 1996) and models of temporal lobe epilepsy (Sloviter, 1991; Simmons et al., 1997; Bra- 

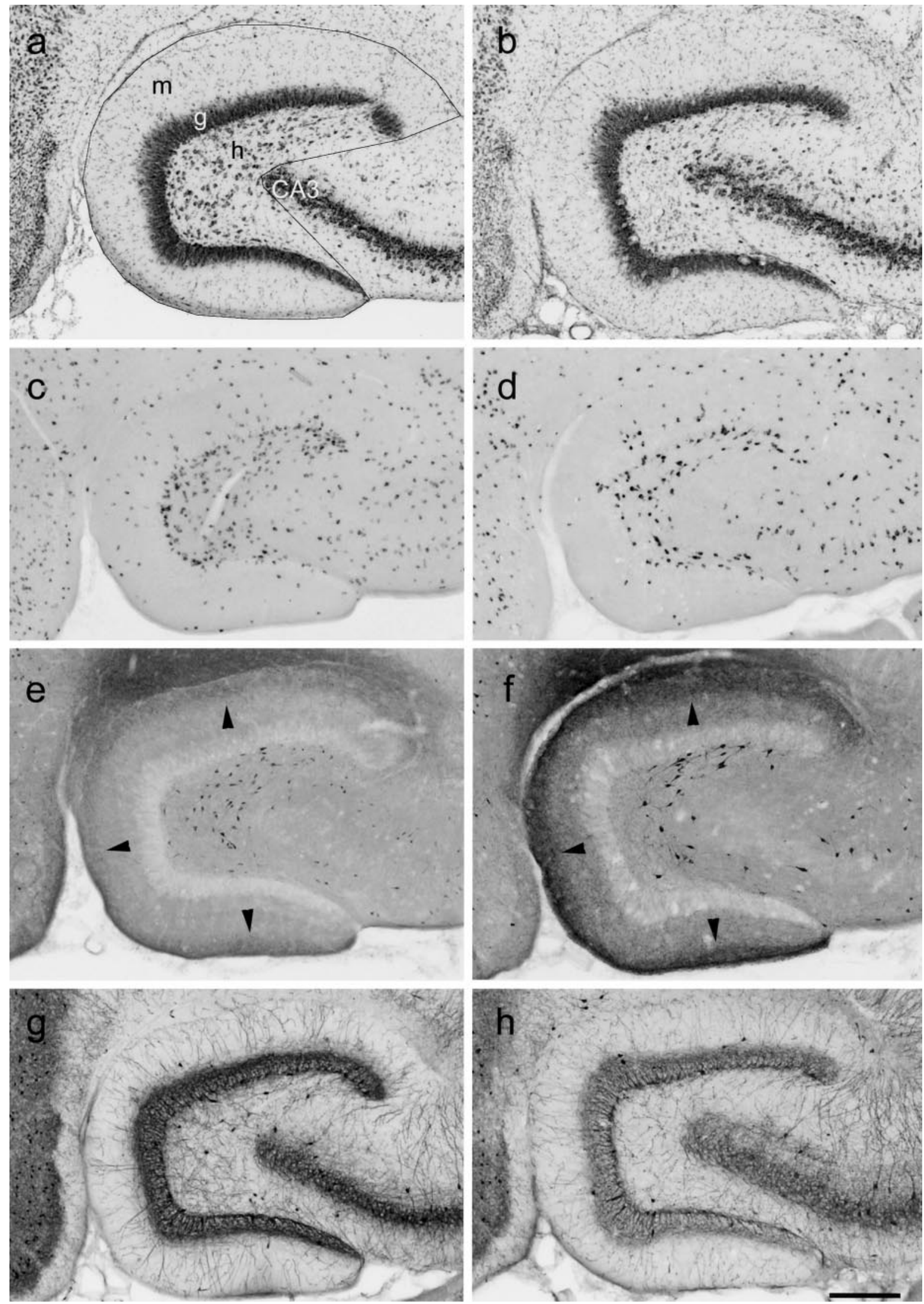

Figure 1. Interneuron loss in the dentate gyrus of a pilocarpine-induced epileptic rat. Nissl-staining $(a, b)$, GAD65 mRNA in situ hybridization $(c, d)$, and somatostatin $(e, f)$ and parvalbumin immunocytochemistry $(g, h)$ demonstrate the loss of interneurons in adjacent sections from an epileptic rat $(b, d, f, h)$ compared with a control $(a, c, e, g)$. GAD65 mRNA expression appears more intense in surviving interneurons in the epileptic rat ( $d$ ) compared with the control (c). The surviving somatostatin-immunoreactive somata and axons in the outer molecular layer (arrowheads) are labeled more intensely in the epileptic rat $(f)$ compared with the control (e). Interneuron profiles (GAD65 mRNA-, somatostatin-, and parvalbumin-positive) were counted within the borders of the dentate gyrus that are demonstrated in $a$. Nissl-stained hilar neurons were counted only within the hilus $(h)$. $m$, Molecular layer; $g$, granule cell layer; CA3, CA3 pyramidal cell layer. Scale bar, $250 \mu \mathrm{m}$. 

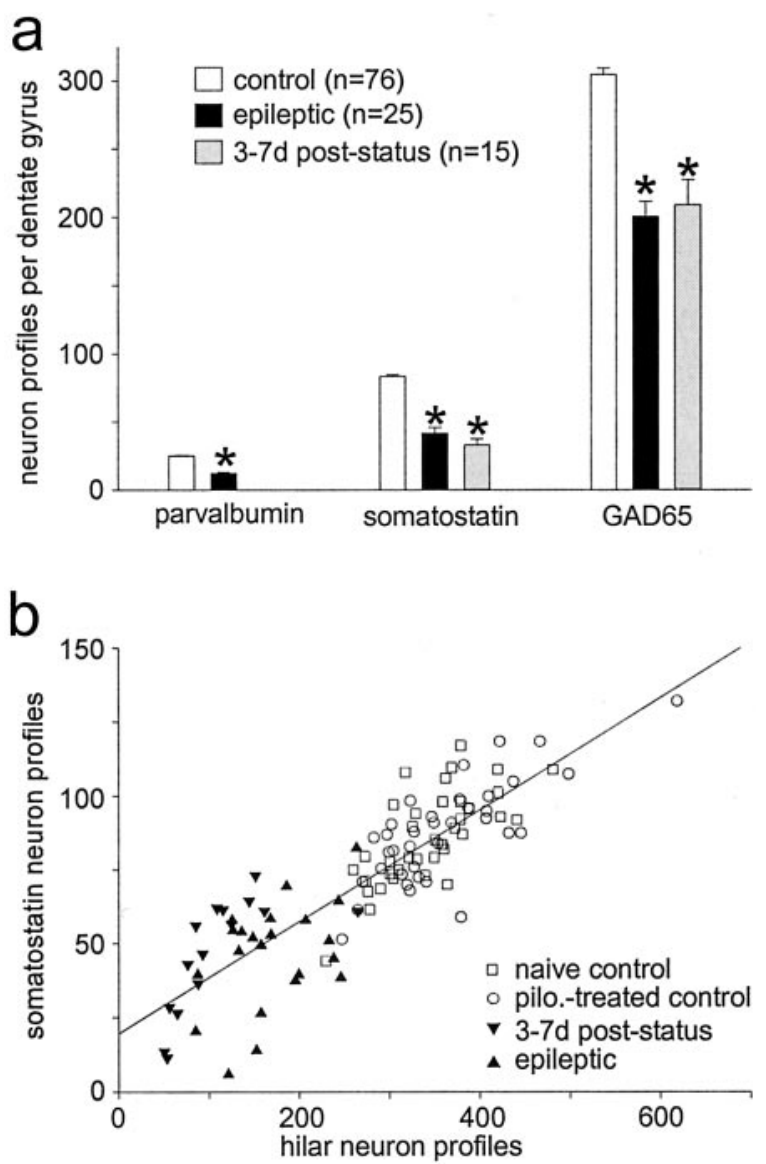

Figure 2. Analysis of interneuron loss in the dentate gyrus of pilocarpine-induced epileptic rats and in rats 3-7 d after status epilepticus. a, Parvalbumin- and somatostatinimmunoreactive and GAD65 mRNA-positive interneuron profiles were counted in the most dorsal (Fig. 1) and the most ventral slice prepared from each rat. Slices between were used for electrophysiology. The number of interneuron profiles per dentate gyrus for each rat was calculated by averaging the values from the most dorsal and the most ventral slice. The averages of each experimental group are plotted in this graph. Epileptic and 3-7 d post-status epilepticus rats had fewer interneurons than did controls ( ${ }^{*} p<0.0001$; unpaired $t$ test). Parvalbuminpositive interneurons could not be analyzed in $3-7 \mathrm{~d}$ post-status epilepticus rats (see Results). Error bars indicate SEM. $b$, The number of somatostatin-immunoreactive interneuron profiles per dentate gyrus was correlated with the number of Nissl-stained hilar neurons from the same slice $(r=0.86)$. Analysis of only the data from epileptic and 3-7 d post-status epilepticus rats also revealed a significant correlation ( $p<0.005$; Spearman Rho test).

gin et al., 1999; Buckmaster and Dudek, 1999; Patrylo et al., 1999; Lynch and Sutula, 2000).

Changes in glutamate receptors (Mody and Heinemann, 1987; Mathern et al., 1998) and excitatory circuitry might enhance excitatory synaptic input to granule cells and make them hyperexcitable. We found evidence of changes in excitatory circuitry that included abnormal morphological characteristics reported previously for granule cells in epileptic tissue (Fig. 4) (Represa et al., 1993; Franck et al., 1995; Okazaki et al., 1995; Spigelman et al., 1998; Sutula et al., 1998; Buckmaster and Dudek, 1999; Ribak et al., 2000). At least one axon collateral from a biocytin-labeled granule cell projected into the molecular layer in $91 \%$ of the 34 slices from epileptic rats (Fig. $4 c$ ) and in only $19 \%$ of the 27 slices from controls $\left(p<0.005 ; \chi^{2}\right.$ test). Mild mossy fiber invasion of the inner molecular layer occurs in the temporal pole of control rats (Cavazos et al., 1992; Buckmaster and Dudek, 1997).

Basal dendrites were evident in $31 \%$ of the 108 labeled granule cells in epileptic rats (Fig. $4 b$ ) and in only $5 \%$ of the 58 cells in
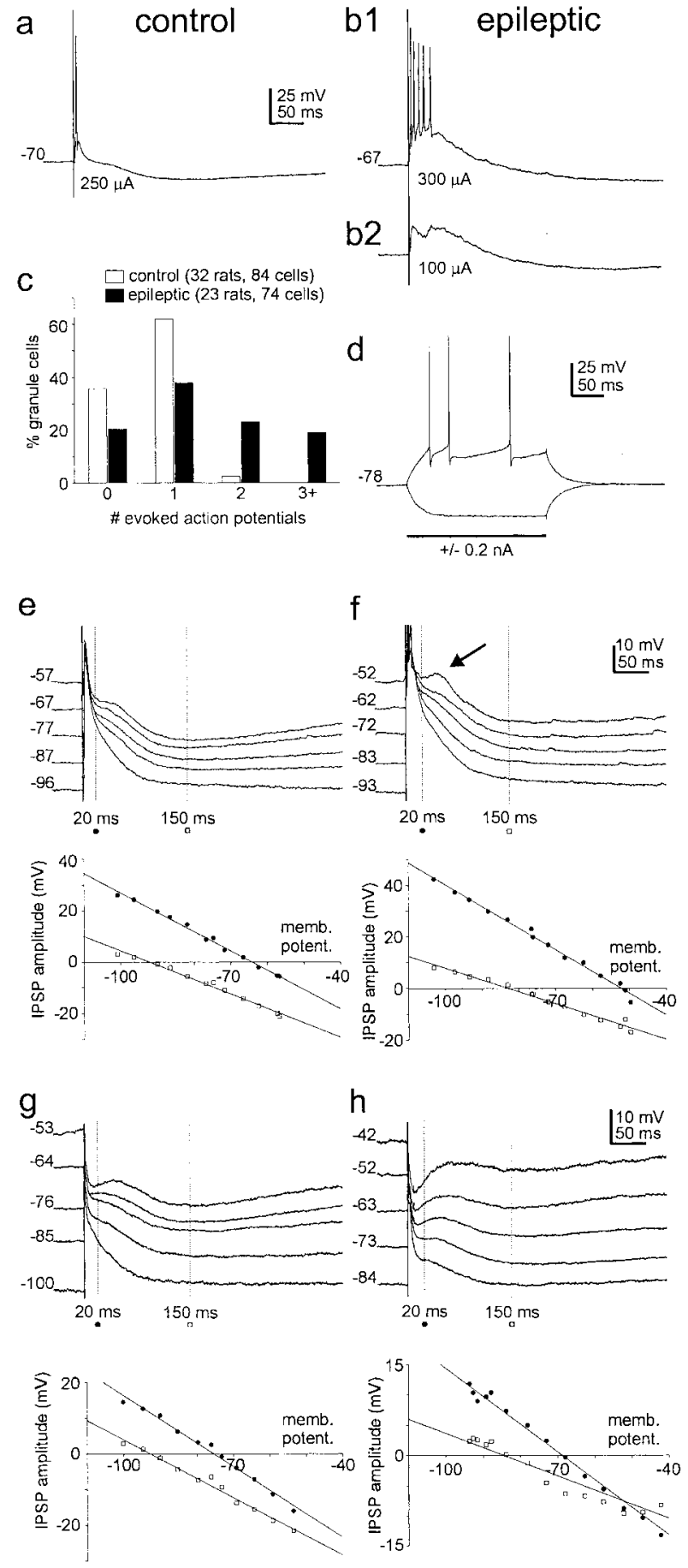

Figure 3. Granule cells in epileptic rats are hyperexcitable and less inhibited. Sharp electrode, current-clamp recordings of responses evoked by outer molecular layer stimulation reveal one action potential in the granule cell from a control rat $(a)$ and five action potentials in the granule cell from an epileptic rat $(b 1) .62$, Lower stimulation intensity revealed a prolonged depolarization in the granule cell from an epileptic rat. $c$, Granule cells in epileptic rats discharged more action potentials than controls ( $p<0.0001$; unpaired $t$ test). $d$, Granule cells from epileptic (and control) rats did not discharge bursts of action potentials in response to injected current steps. $e-h$, Representative examples of IPSPs evoked by molecular layer stimulation and recorded at a range of holding currents. Evoked potentials were analyzed at latencies of 20 and $150 \mathrm{msec}$, which are near the peaks of the early and late IPSPs, respectively. IPSPs recorded in normal ACSF in control $(e)$ and epileptic rats $(f)$. Action potentials evoked in the epileptic tissue are clipped. $f$, The reversal potential at the 20 msec latency in the epileptic rat was more depolarized (arrow). $g$, $h$, Monosynaptic IPSPs recorded in the presence of CNQX/DAPV. Reversal potentials were similar in the epileptic rat $(h)$ and control $(g)$ (Table 1). 

intracellular electrodes

\begin{tabular}{|c|c|c|c|c|}
\hline & Control & $n$ (cells) & Epileptic & $n$ (cells) \\
\hline Input resistance $(M \Omega$ ) & $102 \pm 8$ & 37 & $110 \pm 11$ & 26 \\
\hline $\begin{array}{l}\text { Resting membrane potential (mV) } \\
\text { Normal ACSF }\end{array}$ & $-77 \pm 1$ & 37 & $-76 \pm 2$ & 26 \\
\hline Stimulation intensity (mA) & $0.34 \pm 0.04$ & 33 & $0.35 \pm 0.05$ & 25 \\
\hline \multicolumn{5}{|l|}{20 msec latency } \\
\hline Conductance (nS) & $26.5 \pm 2.2$ & 33 & $19.7 \pm 3.9$ & 25 \\
\hline Reversal potential (mV) & $-60 \pm 1$ & 33 & $-51 \pm 2^{* * *}$ & 25 \\
\hline \multicolumn{5}{|l|}{150 msec latency } \\
\hline Conductance (nS) & $9.8 \pm 0.8$ & 33 & $7.5 \pm 1.0$ & 25 \\
\hline Reversal potential (mV) & $-91 \pm 1$ & 33 & $-91 \pm 2$ & 25 \\
\hline \multicolumn{5}{|l|}{ CNQX/D-APV } \\
\hline Stimulation intensity $(\mathrm{mA})$ & $2.88 \pm 1.20$ & 8 & $5.28 \pm 1.24$ & 9 \\
\hline \multicolumn{5}{|l|}{20 msec latency } \\
\hline Conductance (nS) & $44.1 \pm 15.3$ & 8 & $10.2 \pm 1.7^{*}$ & 9 \\
\hline Reversal potential (mV) & $-71 \pm 2$ & 8 & $-67 \pm 1$ & 9 \\
\hline \multicolumn{5}{|l|}{150 msec latency } \\
\hline Conductance (nS) & $16.1 \pm 3.3$ & 8 & $5.2 \pm 1.0^{* *}$ & 9 \\
\hline Reversal potential (mV) & $-90 \pm 2$ & 8 & $-92 \pm 3$ & 9 \\
\hline
\end{tabular}

Stimulation of the outer molecular layer was set at an intensity that evoked a maximum amplitude IPSP at a 150 msec latency. Stimulation intensity was reset after switching to CNQX/D-APV. Synaptic responses were measured at latencies of 20 and $150 \mathrm{msec}$, which are near the peaks of the early and late IPSPS, respectively. Values represent mean \pm SEM. ${ }^{*} p<0.03 ;{ }^{* *} p<0.005 ;{ }^{* * *} p<0.001$; unpaired $t$ test.
Table 1. Granule cell intrinsic physiology and evoked responses recorded with current-clamp and sharp

rats were lower than those of controls (74 and $77 \%$ of controls, respectively), but the differences were not significant (unpaired $t$ test) (Table 1). The reversal potential at 20 msec was significantly more depolarized in epileptic rats (Fig. $3 f$ ), probably because the early IPSP was more contaminated by prolonged EPSPs.

Hyperexcitability of principal neurons amplifies excitatory synaptic input to interneurons, thereby enhancing feedback inhibition (Chagnac-Amitai and Connors, 1989b). Therefore, in normal ACSF there is a potential for polysynaptic amplification of IPSPs in tissue from epileptic rats, because their granule cells discharge more action potentials and may excite surviving postsynaptic interneurons more than in controls. To block polysynaptic amplification, we applied CNQX/D-APV and recorded monosynaptic IPSPs (Figs. $3 g, h$ ). Monosynaptic IPSPs in control and epileptic rats had similar reversal potentials (Table 1). The reversal potential of the controls $\left(p<0.005 ; \chi^{2}\right.$ test). We measured the distance from the closest edge of the soma of biocytin-labeled granule cells to the hilar/granule cell layer border. Granule cells with basal dendrites were closer to the border $(13 \pm 3 \mu \mathrm{m}$; range, $0-80 \mu \mathrm{m})$ than granule cells without basal dendrites ( $29 \pm 2 \mu \mathrm{m}$; range, $0-88$ $\mu \mathrm{m} ; p<0.002$; unpaired $t$ test). Previous studies found fewer granule cells with basal dendrites in epileptic rats and virtually no granule cells with basal dendrites in control rats (Spigelman et al., 1998; Buckmaster and Dudek, 1999; Ribak et al., 2000). Possible causes for the different results include the septotemporal level examined and how status epilepticus was initiated and terminated in different experimental models. Regardless of these differences, the presence of axon projections into the molecular layer and the presence of basal dendrites might contribute to granule cell hyperexcitability through novel recurrent excitatory circuits in epileptic rats.

\section{Reduced monosynaptic IPSPs in epileptic rats}

In addition to recurrent excitation through sprouted mossy fibers and granule cell basal dendrites, the loss of inhibitory interneurons may contribute to granule cell hyperexcitability. IPSPs were recorded with sharp intracellular electrodes and current clamp while DC current injection was used to collect a family of evoked responses at different baseline membrane potentials. The outer molecular layer was stimulated because it is a region where the axons of a vulnerable population of GABAergic interneurons concentrate and synapse with granule cell dendrites (Leranth et al., 1990; Katona et al., 1999; Buckmaster et al., 2002a). In normal ACSF, this stimulation method is likely to evoke a mixture of monosynaptic and polysynaptic responses through feedforward and feedback circuits. Synaptic conductances were calculated at latencies of 20 and $150 \mathrm{msec}$, which are near the peaks of the early $\mathrm{GABA}_{\mathrm{A}}$ receptor-mediated and late $\mathrm{GABA}_{\mathrm{B}}$ receptor-mediated IPSPs, respectively (Fig. $3 e, f$ ). IPSP conductances were slightly higher than those recorded in the septal dentate gyrus in vivo with angular bundle stimulation (Buckmaster and Dudek, 1999), and they were similar to those reported for human granule cells in slice experiments (Williamson et al., 1999). In normal ACSF the average conductances at 20 and $150 \mathrm{msec}$ latencies in epileptic early IPSP in control and epileptic rats was more negative in CNQX/D-APV than in normal ACSF, probably because contaminating EPSPs had been blocked. In epileptic rats the mean conductances of monosynaptic IPSPs at 20 and $150 \mathrm{msec}$ latencies were reduced to 23 and $32 \%$ of control values, respectively (Table 1).

\section{Increased paired-pulse facilitation of IPSCs in epileptic rats}

Previous studies have used paired-pulse stimulation to evaluate inhibition of the dentate gyrus in epileptic and control tissue (Tuff et al., 1983; Uruno et al., 1995; Buhl et al., 1996; Haas et al., 1996; Buckmaster and Dudek, 1997; Wilson et al., 1998). To test paired-pulse depression of $\mathrm{GABA}_{\mathrm{A}}$ receptor-mediated IPSCs we stimulated the outer molecular layer with bipolar wire electrodes (15 $\mu \mathrm{m}$ diameter) under application of CNQX and D-APV (Fig. $5 a)$. Low-intensity stimuli elicited no response, but gradual increases (to 26-65 $\mu \mathrm{A}, 80 \mu \mathrm{sec}, 0.1 \mathrm{~Hz}$ ) evoked IPSCs in an allor-none manner. Stimulation intensity was set at $1.5 \times$ the threshold for minimal responses. IPSCs were completely blocked by application of bicuculline methiodide (data not shown), indicating that they were mediated by $\mathrm{GABA}_{\mathrm{A}}$ receptors. In the control group, paired-pulse depression of monosynaptic IPSCs was observed, especially at shorter interstimulus intervals. In epileptic animals, instead of paired-pulse depression, IPSCs displayed paired-pulse facilitation when stimuli were delivered at intervals $\geq 100 \mathrm{msec}$ (Fig. 5b).

Fewer IPSCs in epileptic and 3-7 d post-status epilepticus rats As described above, our evoked response analyses of granule cell inhibition yielded mixed results. Granule cells in epileptic rats had smaller conductance monosynaptic IPSPs, but their monosynaptic IPSCs were less depressed during paired-pulse stimulation. Intense electrical stimulation of the molecular layer is nonphysiological, and evoked responses may reflect the activation of both synaptic and extrasynaptic receptors. Therefore, we evaluated sIPSCs, which reflect a more physiological form of $\mathrm{GABA}_{\mathrm{A}}$ receptor-mediated inhibition. In normal ACSF the frequency and charge transfer of sIPSCs in epileptic rats was reduced (51 and $72 \%$ of controls) (Fig. $6 a, c$ ). These findings suggest that in 

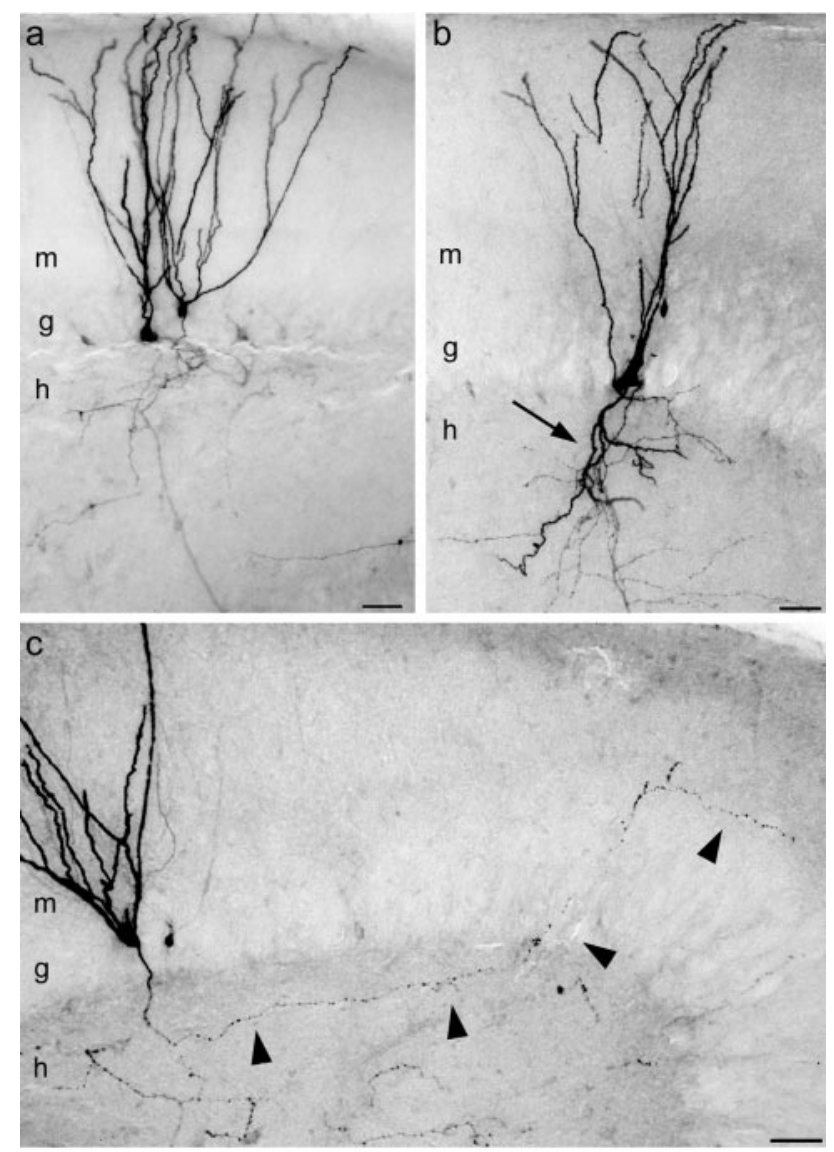

Figure 4. Morphological evidence for changes in the excitatory circuitry of granule cells in epileptic rats. $a$, Biocytin-labeled granule cells in a control rat extended dendrites into the molecular layer $(\mathrm{m})$ and axons into the hilus $(h) \cdot b, \ln$ an epileptic rat, one of two labeled granule cells extended a basal dendrite into the hilus (arrow).c, In an epileptic rat, an axon collateral (arrowheads) projected from the hilus, through the granule cell layer $(g)$, and into the molecular layer. Scale bars, $50 \mu \mathrm{m}$.

epileptic rats, granule cells receive less spontaneous inhibitory synaptic input than in controls. The reduced frequency of sIPSCs could be caused by reduced spontaneous activity of presynaptic interneurons or fewer inhibitory synapses on granule cells, or both. If there were fewer inhibitory synapses on granule cells, the frequency of mIPSCs should be reduced. Therefore, we evaluated mIPSCs under application of CNQX, D-APV, and tetrodotoxin. Bicuculline methiodide completely blocked mIPSCs (data not shown). In epileptic rats the frequency of mIPSCs was reduced to $47 \%$ of controls (Fig. $7 a, c$ ).

To determine whether inhibitory synaptic input to granule cells decreased before or after the onset of epilepsy, we recorded sIPSCs and mIPSCs in 3-7 d post-status epilepticus rats. Spontaneous IPSCs recorded in 3-7 d post-status epilepticus rats were less frequent and transferred less charge (30 and $42 \%$ of agematched controls, respectively) (Fig. $6 b, c$ ). Shortly after status epilepticus, excitatory synaptic drive onto dentate interneurons is reduced (Doherty and Dingledine, 2001). That might explain, in part, why sIPSC frequency was lowest in 3-7 d post-status epilepticus rats compared with all other groups. Similarly, mIPSC frequency was reduced to $36 \%$ of controls (Figs. $7 b, c$ ). These results suggest that in pre-epileptic rats, before the onset of epilepsy, granule cells receive less inhibitory synaptic input.

The average amplitude of sIPSCs in epileptic rats was $143 \%$ of controls (Fig. $6 c$ ). This could be attributable to larger amplitude IPSCs per synapse or to more synchronous synaptic release. The

\section{a Control}

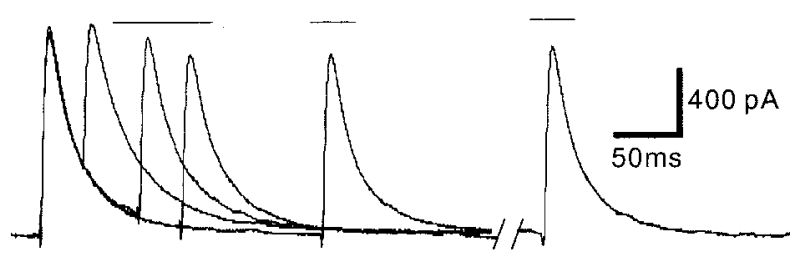

\section{Epileptic}
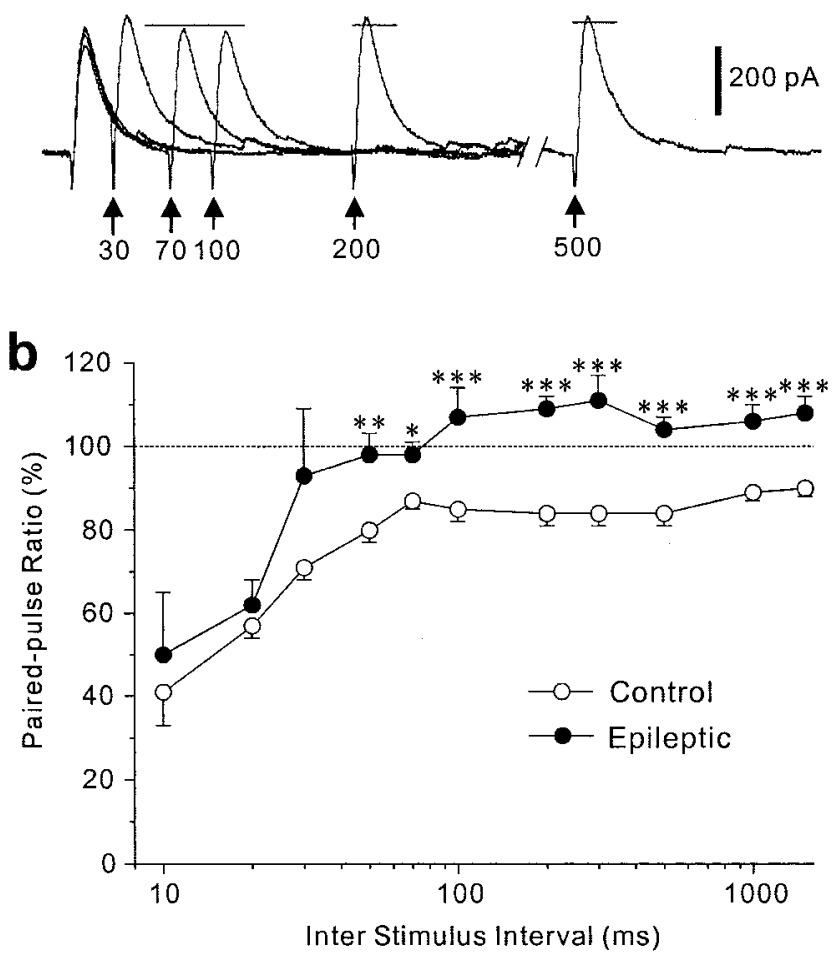

Figure 5. Reduced paired-pulse depression of monosynaptic $G A B A_{A}$ receptor-mediated IPSCS recorded with whole-cell voltage clamp in granule cells from epileptic rats. IPSCs were evoked by outer molecular layer stimulation. $a$, Superimposed pairs of evoked IPSCs at interstimulus intervals of $30,70,100,200$, and $500 \mathrm{msec}$ (average of 4 trials). Horizontal bars indicate the average peak of the first response. $b$, Time course of paired-pulse responses in controls $(n=$ 13) and epileptic animals $(n=10)$. Error bars indicate SEM. ${ }^{*} p<0.05 ;{ }^{* *} p<0.01$; ${ }^{* * *} p<$ 0.001 (unpaired $t$ test).

average amplitude of mIPSCs in epileptic rats was $137 \%$ of controls (Fig. 7c), suggesting increased IPSC amplitude per synapse. In granule cells from kindled animals, mIPSC amplitude is increased, and more $\mathrm{GABA}_{\mathrm{A}}$ receptors are expressed per synapse (Otis et al., 1994; Nusser et al., 1998).

The average 10-90\% rise time of sIPSCs in granule cells from epileptic rats was similar to age-matched controls, although the average $10-90 \%$ rise time in 3-7 d post-status epilepticus was smaller than that of controls (Fig. 6c). Rise times of mIPSCs were similar in all groups (Fig. 7c). These findings suggest that interneurons generating slow-rising IPSCs might be transiently and selectively inactive after status epilepticus.

As mentioned above, the average frequency of mIPSCs in epileptic and 3-7 d post-status epilepticus rats decreased to $<50 \%$ of controls. The average frequency of mIPSCs in chronically epileptic rats $(4.5 \pm 0.4 \mathrm{~Hz})$ was similar to that in $3-7 \mathrm{~d}$ post-status epilepticus rats (3.9 $\pm 0.4 \mathrm{~Hz} ; p>0.1$; unpaired $t$ test) (Fig. $7 c$ ). These results suggest that granule cells lose more than half of their inhibitory synapses within $3 \mathrm{~d}$ of pilocarpine-induced status epi- 

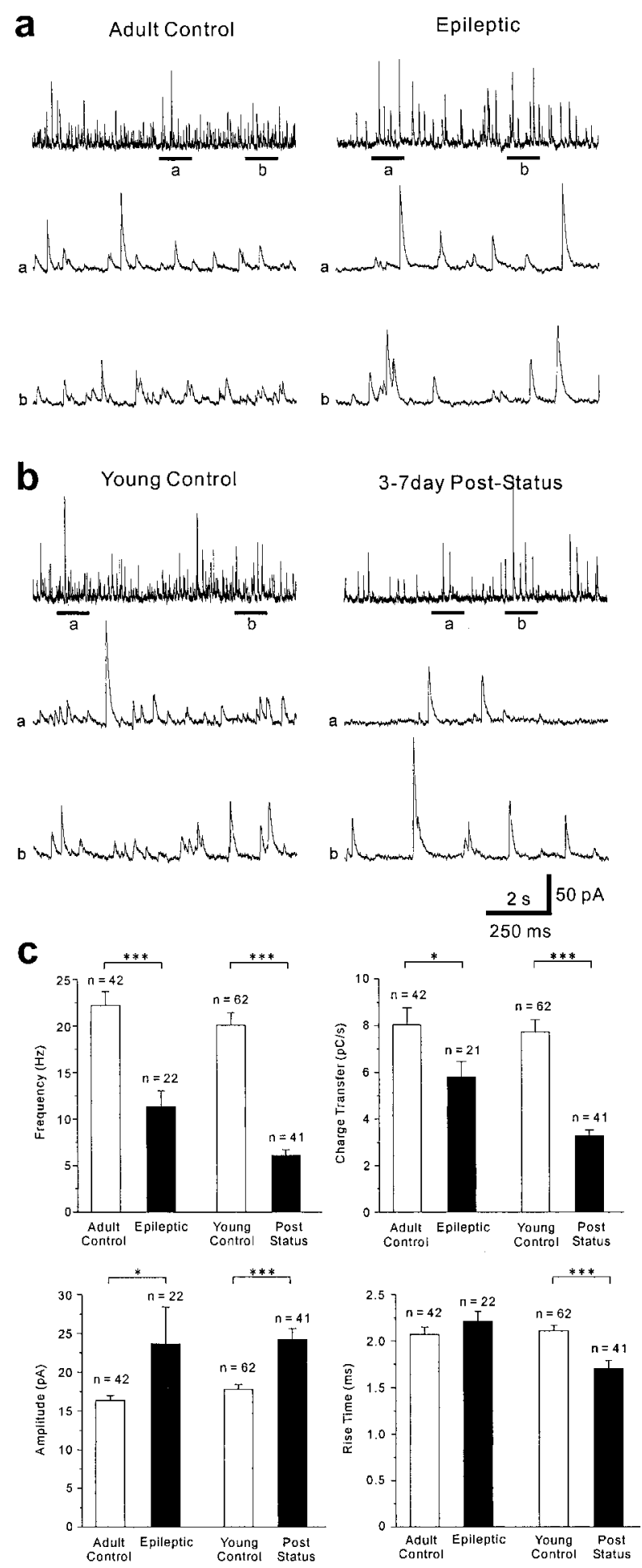

Figure 6. Fewer spontaneous IPSCs recorded in normal ACSF in epileptic (a) and 3-7 d post-status epilepticus rats $(b)$ compared with their respective controls. $a, b$, Middle and bottom traces show time-expanded view of regions indicated by bars under top traces. c, Frequency, charge transfer, amplitude, and 10-90\% rise time of spontaneous IPSCs in each group. Error bars indicate SEM. ${ }^{*} p<0.05 ;{ }^{* * *} p<0.001$ (unpaired $t$ test).

lepticus, and this loss is maintained into the stage of chronic epilepsy.

Which inhibitory inputs to granule cells are lost?

Granule cells receive inhibitory synaptic input at proximal/somatic and distal/dendritic sites (Halasy and Somogyi, 1993).
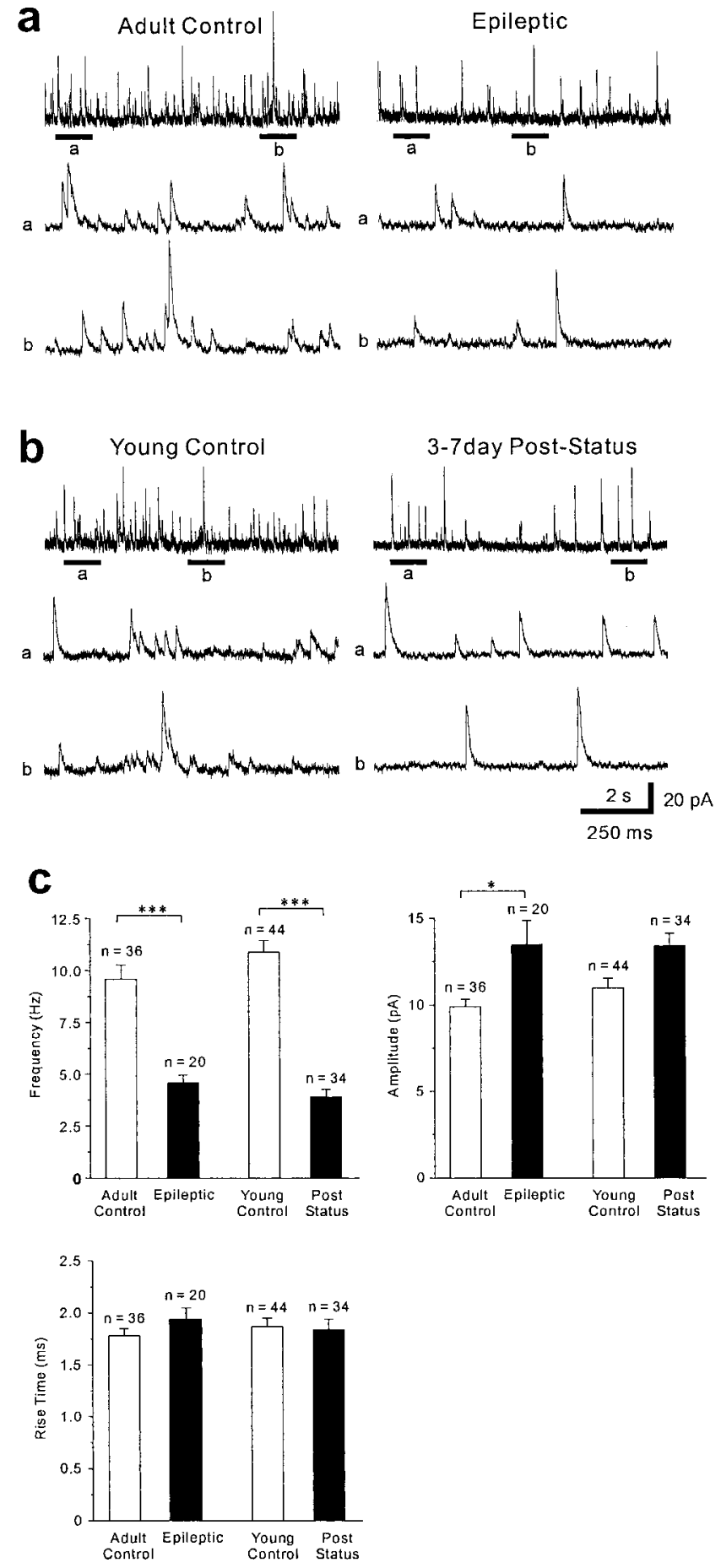

Figure 7. Fewer miniature IPSCs recorded in CNQX/D-APV/TTX in epileptic $(a)$ and 3-7 d post-status epilepticus rats $(b)$ compared with their respective controls. $a, b$, Middle and bottom traces show time-expanded view of regions indicated by bars under top traces. c, Frequency, amplitude, and $10-90 \%$ rise time of miniature IPSCs in each group. Error bars indicate SEM. ${ }^{*} p<0.05 ;{ }^{* *} p<0.01 ;{ }^{* * *} p<0.001$ (unpaired $t$ test).

When measured at the soma, synaptic events generated in the distal dendrites of granule cells are slower rising and smaller in amplitude than those generated more proximally (Soltesz et al., 1995). To verify this we evoked IPSCs by minimal stimulation under application of CNQX and D-APV in control granule cells. Stimulating electrodes were positioned in the outer molecular layer and granule cell layer (Fig. 8a). Minimal stimulation (30 \pm 

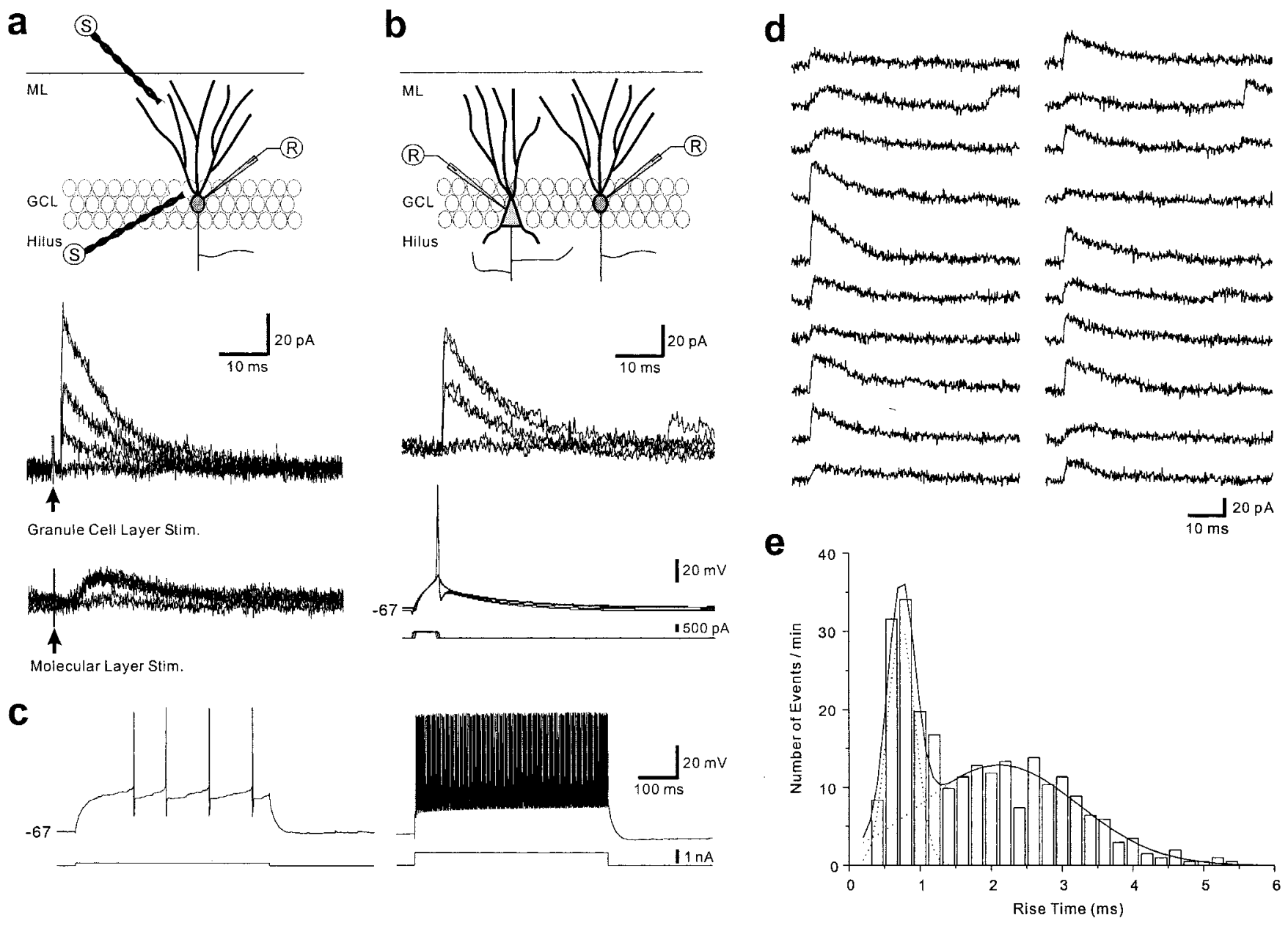

Figure 8. Two types of $\mathrm{AABA}_{A}$ receptor-mediated mIPSCs in granule cells based on $10-90 \%$ rise times. $a$, In a granule cell from a control rat, minimal stimulation of outer molecular layer evoked slower rise time and smaller amplitude IPSCs compared with minimal stimulation of the granule cell layer. $b$, Paired whole-cell patch-clamp recording from a putative basket cell and a granule cell. Action potentials evoked by a short-duration current pulse injected into the basket cell generated fast-rising and large-amplitude unitary IPSCs in the granule cell. Traces were aligned at the peak time of the action potential. ML, Molecular layer; $G C L$, granule cell layer; $S$, stimulation electrode; $R$, recording electrode. $c$, Responses of a putative basket cell (same as one shown in $b$ ) display nonadapting repetitive firing to a small (left side) and a larger (right side) current step. $d$, Consecutive mIPS(s in a granule cell from an epileptic rat arranged in columns from the top trace of the left panel to the bottom trace of the right panel. e, Distribution of $10-90 \%$ rise times of mIPSCs obtained from the same cell as shown in $d$. The distribution was fit with two Gaussians (dotted lines). The thick line shows the summation of these curves.

$1 \mu \mathrm{A}$ in the granule cell layer; $51 \pm 2 \mu \mathrm{A}$ in the molecular layer; $p<0.001$; paired $t$ test) failed to evoke an IPSC $38 \pm 6 \%$ of the time in the granule cell layer and $39 \pm 6 \%$ of the time in the molecular layer $(n=13)$. Minimal stimulation of the granule cell layer evoked large-amplitude $(91.8 \pm 15.0 \mathrm{pA})$ fast-rising $(1.2 \pm$ 0.2 msec; $10-90 \%$ rise time) IPSCs with stepwise variations in amplitude. In the same granule cells, minimal stimulation of the outer molecular layer evoked smaller-amplitude $(28.3 \pm 4.7 \mathrm{pA}$; $p<0.001$; $t$ test $)$ slower-rising $(3.7 \pm 0.3 \mathrm{msec} ; p<0.001$; paired $t$ test) IPSCs.

To confirm that our minimal stimulation protocol evoked unitary synaptic responses, we obtained recordings from basket cells and synaptically coupled granule cells in control rats $(n=5)$. Putative basket cells were identified by their large pyramidalshaped soma positioned between the granule cell layer and hilus (Kosaka et al., 1987), short-duration action potentials (data not shown), and fast spiking without adaptation in response to sustained current injection (Kraushaar and Jonas, 2000) (Fig. 8c). Action potentials in presynaptic basket cells evoked unitary IPSCs in postsynaptic granule cells (Fig. $8 b$ ) with similar amplitudes $(91.1 \pm 24.5 \mathrm{pA})$ and rise times $(1.1 \pm 0.2 \mathrm{msec})$ as IPSCs evoked by minimal stimulation in the granule cell layer. The average rise time was longer than that reported by Kraushaar and Jonas (2000), but they measured $20-80 \%$ rise time in chloride-loaded cells at a higher temperature. Our findings confirm that spontaneous and miniature IPSCs generated at proximal/somatic sites are likely to have fast rise times and large amplitudes, whereas those generated at distal/dendritic sites will tend to have slower rise times and smaller amplitudes. Similarly, CA1 pyramidal neurons have fast- and slow-rising $\mathrm{GABA}_{\mathrm{A}}$ receptor-mediated IPSCs (Wierenga and Wadman, 1999) that are generated at somatic and dendritic sites, respectively (Banks et al., 1998).

To determine whether there was a selective loss of fast- or slow-rising $\mathrm{GABA}_{\mathrm{A}}$ receptor-mediated events in epileptic rats, we constructed histograms of the $10-90 \%$ rise-times of mIPSCs in individual granule cells. Those histograms were well fit by two Gaussian distributions (Fig. 8e), suggesting that mIPSCs can be divided into two groups. The average $10-90 \%$ rise times were $0.88 \mathrm{msec}$ for the fast-rising and $2.09 \mathrm{msec}$ for the slow-rising group. IPSC rise time depends on $\mathrm{GABA}_{\mathrm{A}}$ receptor subunit composition in the postsynaptic membrane and site of origin on the recorded cell. Although we did not obtain direct recordings from 
Table 2. Properties of fast- and slow-rising $\mathrm{GABA}_{\mathrm{A}}$ receptor-mediated mIPSCs

\begin{tabular}{lllll}
\hline & Adult control & Epileptic & Young control & $3-7 \mathrm{~d}$ post-status \\
\hline $\begin{array}{l}\text { Number of cells } \\
\text { Fast-rising mIPSCs }\end{array}$ & 12 & 16 & 15 & 30 \\
$\quad$ 10-90\% rise time (msec) & $0.89 \pm 0.06$ & $0.86 \pm 0.05$ & $0.93 \pm 0.07$ & $0.84 \pm 0.04$ \\
$\quad$ Proportion & $0.29 \pm 0.03$ & $0.30 \pm 0.01$ & $0.27 \pm 0.02$ & $0.33 \pm 0.03$ \\
$\quad$ Amplitude (pA) & $10.9 \pm 1.1^{\#}$ & $19.8 \pm 3.7^{\# \#, *}$ & $10.7 \pm 0.9^{\#}$ & \\
Slow-rising mIPSCs & & & & \\
$\quad 10-90 \%$ rise time (msec) & $2.11 \pm 0.08$ & $2.17 \pm 0.11$ & $2.02 \pm 0.14$ & $2.05 \pm 0.09$ \\
Proportion & $0.71 \pm 0.03$ & $0.70 \pm 0.01$ & $0.73 \pm 0.02$ & $0.67 \pm 0.03$ \\
$\quad$ Amplitude (pA) & $8.8 \pm 0.7$ & $9.9 \pm 0.5$ & $9.2 \pm 0.7$ & $11.3 \pm 0.6^{*}$ \\
\hline
\end{tabular}

Histograms of mIPSC rise times from individual cells were fit with two Gaussian curves (Fig. 8e). From the two Gaussian curves, the average rise times of fast-rising and slow-rising events were calculated. Those results were compiled for cells from animals in all four experimental groups, and the values in this Table represent the means \pm SEM. There were no significant differences in the average rise times or proportion of fast- versus slow-rising events between epileptic, $3-7$ $d$ post-status epilepticus, and control rats ( $t$ test). Average amplitudes of the fastest fast-rising ( $10-90 \%$ rise time less than the median minus 1 SD) and the slowest slow-rising (10 - $90 \%$ rise time more than the median plus 1 SD) were calculated and are shown in this Table. Within each experimental group, the average amplitudes of the fastest fast-rising mIPSCs were larger than the average amplitudes of the slowest slow-rising mIPSCs $(\# p<0.05 ; \#$; $p<0.001 ;$ paired $t$ test). The average amplitude of the fastest fast-rising mIPS(s in epileptic rats was $182 \%$ of that of adult controls ( ${ }^{*} p<0.05$; unpaired $t$ test). Similarly, the average amplitude of the fastest fast-rising mIPS(s in $3-7 \mathrm{~d}$ post-status epilepticus rats was $160 \%$ of that of young controls $\left({ }^{* *} p<0.001\right.$; unpaired $t$ test). The average amplitude of the slowest slow-rising mIPSCs in $3-7$ d post-status epilepticus rats was $123 \%$ of that of young controls ( ${ }^{*} p<0.05$; unpaired $t$ test).

granule cell dendrites, the similarity of rise times of mIPSCs and IPSCs evoked by minimal stimulation of the outer molecular layer suggests that slow-rising mIPSCs are generated in the dendrites. Evoked responses might be slightly slower because stimulating electrodes were placed in the outermost edge of the molecular layer, whereas mIPSCs may arise all along the dendritic arbor. Fast- and slow-rising events accounted for an average of 30 and $70 \%$ of the mIPSCs, respectively (Table 2), which is similar to the proportion of somatic versus dendritic GABAergic synapses on granule cells (25 and 75\%, respectively) (Halasy and Somogyi, 1993).

As mentioned previously, the average amplitudes of granule cell mIPSCs were larger in epileptic and 3-7 d post-status epilepticus rats compared with controls. After categorizing mIPSCs as fast or slow rising by fitting histograms with two Gaussian curves, it was possible to determine whether the amplitudes of fast-rising mIPSCs, slow-rising mIPSCs, or both were larger in granule cells recorded from epileptic and 3-7 d post-status epilepticus rats compared with controls. For this analysis, mIPSCs were subdivided into two extreme categories: the fastest fast-rising mIPSCs and the slowest slow-rising mIPSCs. The fastest fast-rising events from each cell were mIPSCs with $10-90 \%$ rise times that were less than the median minus $1 \mathrm{SD}$ in the Gaussian curve that fit the distribution of fast-rising events. The slowest slow-rising events from each cell were mIPSCs with $10-90 \%$ rise times that were more than the median plus 1 SD in the Gaussian curve that fit the distribution of slow-rising events. In all experimental groups, the average amplitudes of the fastest fast-rising mIPSCs were larger than the slowest slow-rising mIPSCs (Table 2). Compared with controls, the amplitudes of both the fastest fast-rising and the slowest slow-rising mIPSCs were larger in epileptic and 3-7 d post-status epilepticus rats. The amplitudes of the fastest fastrising mIPSCs increased more (160-182\% of control values) than the amplitudes of the slowest slow-rising events (113-123\% of control values). These findings suggest that GABAergic synapses that are located at or near the granule cell body display more plasticity than those located on the distal dendrites.

There were no significant differences in the average rise times or proportion of fast- versus slow-rising events between epileptic, 3-7 d post-status epilepticus, and control rats (Table 2). Histograms of the average mIPSC frequency versus rise time reveal fewer fast- and slow-rising events in epileptic and 3-7 d poststatus epilepticus rats compared with their controls (Fig. 9a). Similarly, histograms of the average mIPSC frequency versus amplitude reveal fewer large- and small-amplitude events in epileptic and 3-7 d post-status epilepticus rats compared with their
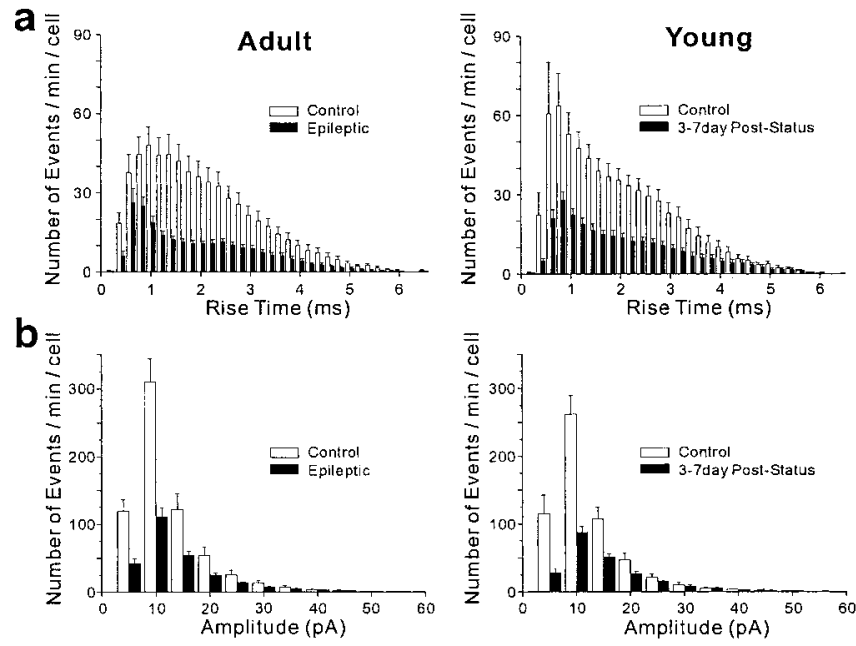

Figure 9. Histograms of average $10-90 \%$ rise times ( $a$ ) and mIPSC amplitudes $(b)$. $a$, Both fast- and slow-rising mIPSCs were less frequent in epileptic and 3-7 d post-status epilepticus rats. b, Both low- and high-amplitude mIPSCs were less frequent in epileptic and 3-7 d poststatus epilepticus rats. Error bars indicate SEM.

respective controls (Fig. 9b). Therefore, our data suggest that in epileptic rats there is a loss of both proximal/somatic and distal/ dendritic GABAergic synapses to granule cells. The mIPSC rise time and amplitude data are consistent with the anatomical results that show a loss of both proximally synapsing parvalbuminimmunoreactive interneurons and distally synapsing somatostatinimmunoreactive interneurons (Figs. $1 e-h, 2 a$ ). This is somewhat different from the situation in the CA1 region where spontaneous inhibition is reduced at the dendritic level but increased at the soma of pyramidal cells (Cossart et al., 2001).

\section{Discussion}

The principal finding of this study is the reduction of granule cell inhibition in a model of temporal lobe epilepsy. The use of multiple techniques to evaluate granule cell inhibition and the comparison of electrophysiological and anatomical data at different stages of epileptogenesis provided new clues about the role of granule cell inhibition in temporal lobe epilepsy.

\section{Reduced granule cell inhibition in epileptic rats}

Our most direct measures of granule cell inhibition (mIPSC and sIPSC frequencies and evoked monosynaptic IPSP conductance) detected reductions to $<50 \%$ of controls. This is a substantial loss, considering that relatively small reductions of $\mathrm{GABA}_{\mathrm{A}}$ re- 
ceptor function to $80-90 \%$ of control values permit the spread of epileptiform activity in neocortex (Chagnac-Amitai and Connors, 1989a). It is likely that the loss of granule cell inhibition is attributable in large part to the loss of inhibitory interneurons. However, reduced mIPSC frequency also could be caused by lower probability of transmitter release (Hirsch et al., 1999). Our findings of reduced inhibitory synaptic input to granule cells in epileptic rats are consistent with some previous studies of tissue from patients with temporal lobe epilepsy. Williamson et al. $(1995,1999)$ found reduced evoked IPSPs in granule cells of epileptic patients. These findings support the hypothesis that interneuron loss in the dentate gyrus reduces granule cell inhibition and contributes to temporal lobe epilepsy (de Lanerolle et al., 1989).

If the reduction in granule cell inhibition is so substantial, why have many previous studies reported strong inhibition in the dentate gyrus of epileptic patients and models (Tuff et al., 1983; Isokawa-Akesson et al., 1989; Franck et al., 1995; Uruno et al., 1995; Colder et al., 1996; Haas et al., 1996; Isokawa, 1996; Buckmaster and Dudek, 1997, 1999; Wilson et al., 1998)? Possible explanations include the septotemporal level examined, the methods used to evaluate granule cell inhibition, and compensatory mechanisms. One's ability to detect reductions in granule cell inhibition might be affected by the septotemporal level of the dentate gyrus. Previous in vivo studies in rats examined the hippocampus at its more accessible septal end. In the present study we used slices from the temporal dentate gyrus, because tissue resected to treat patients with temporal lobe epilepsy includes the temporal (or anterior) dentate gyrus and because it is the region where hilar neuron loss is most severe (Babb et al., 1984) and where the number of GAD-positive (Buckmaster and Jongen-Rêlo, 1999) and somatostatin- and parvalbuminimmunoreactive interneurons are most reduced (Buckmaster and Dudek, 1997). Therefore, studies of the septal dentate gyrus might miss the more severe interneuron loss and reduced granule cell inhibition in the temporal dentate gyrus.

\section{Potential compensatory mechanisms}

Several mechanisms appear to compensate, albeit incompletely, for reduced inhibitory synaptic input to granule cells. Without these compensatory mechanisms, granule cell hyperexcitability might be worse. First, in epileptic rats granule cells discharge more action potentials when stimulated. Therefore, surviving interneurons are likely to receive more excitatory synaptic drive, and that could amplify feedback inhibition of granule cells. Studies that evaluate evoked IPSPs in normal ACSF might overestimate the inhibitory synaptic input to granule cells in epileptic tissue. Second, mIPSC amplitude increases, suggesting that more $\mathrm{GABA}_{\mathrm{A}}$ receptors were expressed per synapse (Otis et al., 1994; Nusser et al., 1998). However, in the present study the increased amplitude of mIPSCs in epileptic rats was offset by the large decrease in MIPSC and sIPSC frequencies, such that the average sIPSC charge transfer was lower than that of controls. Third, paired-pulse depression of IPSCs decreases in granule cells in epileptic rats (Buhl et al., 1996; Haas et al., 1996), consistent with increased paired-pulse inhibition of granule cell-generated field potentials (Tuff et al., 1983; Uruno et al., 1995; Haas et al., 1996; Buckmaster and Dudek, 1997; Wilson et al., 1998). Results from paired-pulse analyses, therefore, suggest that granule cell inhibition would be more persistent during repetitive stimulation in epileptic tissue. Our findings confirm that granule cells from epileptic rats have reduced paired-pulse depression of monosynaptic IPSCs, which could contribute to increased paired-pulse inhi- bition of granule cell discharge. However, that is just one of many factors affecting granule cell inhibition. We found that the less direct measures of granule cell inhibition (conductances of IPSPs evoked in normal ACSF and paired-pulse depression) failed to reveal the loss detected by analysis of sIPSCs, mIPSCs, and evoked monosynaptic IPSPs.

Our data do not support another potential compensatory mechanism. Previous studies described increased staining of inhibitory interneuron fibers in the dentate gyrus molecular layer of patients (Babb et al., 1989; Mathern et al., 1995a) and models of temporal lobe epilepsy (Davenport et al., 1990; Wanscher et al., 1990; Schwarzer et al., 1995; Buckmaster and Dudek, 1997; Mathern et al., 1997; Esclapez and Houser, 1999; Andre et al., 2001). These findings suggested that surviving interneurons might sprout axon collaterals to restore some of the lost inhibitory synaptic input to granule cells. On the other hand, GABAergic axon sprouting might be epileptogenic by producing hypersynchrony (Babb et al., 1989). We, too, found increased staining of somatostatin-immunoreactive fibers in the molecular layer of epileptic rats compared with controls. However, functional evidence for additional, compensatory, GABAergic synapses was lacking. The frequency of mIPSCs in granule cells did not increase significantly from 3 to $7 \mathrm{~d}$ after status epilepticus into the stage of chronic epilepsy. It seems unlikely that new GABAergic synapses at distal dendritic sites went undetected, because we detected IPSCs evoked with minimal stimulation of the outer molecular layer. We cannot exclude the possibility that functional evidence for additional GABAergic synapses would have eventually developed after longer periods of chronic epilepsy, but at the stage examined, glutamatergic axon sprouting and synaptogenesis by granule cells are well established (Mello et al., 1993; Mathern et al., 1998; Okazaki et al., 1999; Wuarin and Dudek, 2001), so one might expect that GABAergic synaptogenesis would have occurred. Perhaps surviving interneurons only appear to sprout axon collaterals, because seizure activity increases antigen expression (Feldblum et al., 1990; Wanscher et al., 1990; Shinoda et al., 1991; Schwarzer et al., 1995; Houser and Esclapez, 1996; Esclapez and Houser, 1999), making preexisting axon collaterals more visible by immunocytochemical methods. Stereological analysis of inhibitory synapse numbers at different stages of epileptogenesis would help resolve this issue.

\section{Previous studies of granule cell mIPSCs}

Some studies have used direct measures of granule cell inhibition in the temporal dentate gyrus and have found results different from ours. Previous studies found a similar frequency of mIPSCs in granule cells of control (Molnár and Nadler, 2000) and pilocarpine-induced epileptic rats (Molnár and Nadler, 2001). In contrast, we found an average decrease to $<50 \%$ of controls. And, previous studies of granule cells found many fast-rising $\mathrm{GABA}_{\mathrm{A}}$-mediated mIPSCs but few slow-rising mIPSCs (Soltesz et al., 1995). In contrast, we found that an average of $70 \%$ of the $\mathrm{GABA}_{\mathrm{A}}$-mediated mIPSCs fit within the slow-rising category. The causes of these differences are unclear, but possibilities include differences in rat strains and experimental models (for example, whether and how status epilepticus was stopped and the consequent effects on excitotoxic damage) and differences in slice preparation, recording, and data analysis techniques. Filtering associated with low-quality recording conditions could produce an artificially high proportion of slow-rising events. This is an unlikely explanation for our data because (1) the series resistances of our recordings were similar to those of previous mIPSC recordings from granule cells (Soltesz et al., 1995), (2) series re- 
sistance was $80 \%$ compensated in our recordings, and (3) all of our recordings included both fast- and slow-rising events from the same cell (Fig. 8). If recording conditions had been poor, then all events should have been filtered.

\section{Functional implications of reduced inhibition}

Our findings suggest that granule cells receive less inhibitory synaptic input in epileptic rats than in controls. Frequencies of sIPSCs and mIPSCs also were reduced in pre-epileptic rats days to weeks before the onset of recurrent, spontaneous seizures. Therefore, reduced granule cell inhibition alone is insufficient to cause epilepsy, because it was present when rats were not experiencing spontaneous seizures. This finding suggests that epileptogenesis requires other changes. Those other changes might include alterations in the excitatory synaptic input to granule cells. Granule cells sprout axon collaterals into the molecular layer (Represa et al., 1993; Franck et al., 1995; Okazaki et al., 1995; Sutula et al., 1998; Buckmaster and Dudek, 1999; Buckmaster et al., 2002b) and extend novel basal dendrites into the hilus (Spigelman et al., 1998; Buckmaster and Dudek, 1999; Ribak et al., 2000). Both developments might take weeks to establish, and both could contribute to the abnormal recurrent excitation of granule cells found in epileptic rats (Molnár and Nadler, 1999; Lynch and Sutula, 2000; Wuarin and Dudek, 2001). Consistent with enhanced recurrent excitation, orthodromically evoked responses of granule cells in epileptic rats displayed prolonged depolarizations and more action potentials compared with controls. Recurrent excitation can be controlled when inhibition is sufficiently strong (Miles and Wong, 1987; Cronin et al., 1992). The findings of the present study suggest that in epileptic rats the inhibitory synaptic input to granule cells is reduced to a level that sometimes fails to control recurrent excitation and seizure activity. Reduced inhibition and inadequate control of recurrent excitation might be common mechanisms that contribute to epileptogenesis in other regions of the hippocampal formation (Morin et al., 1998; Esclapez et al., 1999) and in neocortex (Li and Prince, 2002).

\section{References}

Andre V, Marescaux C, Nehlig A, Fritschy JM (2001) Alterations of hippocampal GABAergic system contribute to spontaneous recurrent seizures in the rat lithium pilocarpine model of temporal lobe epilepsy. Hippocampus 11:452-468.

Babb TL, Brown WJ, Pretorius J, Davenport C, Lieb JP, Crandall PH (1984) Temporal lobe volumetric cell densities in temporal lobe epilepsy. Epilepsia 25:729-740.

Babb TL, Pretorius JK, Kupfer WR, Crandall PH (1989) Glutamate decarboxylase-immunoreactive neurons are preserved in human epileptic hippocampus. J Neurosci 9:2562-2574.

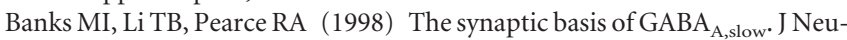
rosci 18:1305-1317.

Bragin A, Engel Jr JE, Wilson CL, Fried I, Mathern GW (1999) Hippocampal and entorhinal cortex high-frequency oscillations $(100-500 \mathrm{~Hz})$ in human epileptic brain and in kainic acid-treated rats with chronic seizures. Epilepsia 40:127-137.

Buckmaster PS, Dudek FE (1997) Neuron loss, granule cell axon reorganization, and functional changes in the dentate gyrus of epileptic kainatetreated rats. J Comp Neurol 385:385-404.

Buckmaster PS, Dudek FE (1999) In vivo intracellular analysis of granule cell axon reorganization in epileptic rats. J Neurophysiol 81:712-721.

Buckmaster PS, Jongen-Rêlo A (1999) Highly specific neuron loss preserves lateral inhibitory circuits in the dentate gyrus of kainate-induced epileptic rats. J Neurosci 19:9519-9529.

Buckmaster PS, Yamawaki R, Zhang GF (2002a) Axon arbors and synaptic connections of a vulnerable population of interneurons in the dentate gyrus in vivo. J Comp Neurol 445:360-373.

Buckmaster PS, Zhang GF, Yamawaki R (2002b) Axon sprouting in a model of temporal lobe epilepsy creates a predominantly excitatory feedback circuit. J Neurosci 22:6650-6658.
Buhl EH, Otis TS, Mody I (1996) Zinc-induced collapse of augmented inhibition by GABA in a temporal lobe epilepsy model. Science 271:369-373.

Cavazos JE, Golarai G, Sutula TP (1992) Septotemporal variation of the supragranular projection of the mossy fiber pathway in the dentate gyrus of normal and kindled rats. Hippocampus 2:363-372.

Chagnac-Amitai Y, Connors BW (1989a) Horizontal spread of synchronized activity in neocortex and its control by GABA-mediated inhibition. J Neurophysiol 61:747-758.

Chagnac-Amitai Y, Connors BW (1989b) Synchronized excitation and inhibition driven by intrinsically bursting neurons in neocortex. J Neurophysiol 61:1149-1162.

Colder BW, Wilson CL, Frysinger RC, Chao LC, Harper RM, Engel J Jr (1996) Neuronal synchrony in relation to burst discharge in epileptic human temporal lobes. J Neurophysiol 75:2496-2508.

Cossart R, Dinocourt C, Hirsch JC, Merchan-Perez A, De Felipe J, Ben-Ari Y, Esclapez M, Bernard C (2001) Dendritic but not somatic GABAergic inhibition is decreased in experimental epilepsy. Nat Neurosci 4:52-62.

Cronin J, Obenaus A, Houser CR, Dudek FE (1992) Electrophysiology of dentate granule cells after kainate-induced synaptic reorganization of the mossy fibers. Brain Res 573:305-310.

Davenport CJ, Brown WJ, Babb TL (1990) Sprouting of GABAergic and mossy fiber axons in dentate gyrus following intrahippocampal kainate in the rat. Exp Neurol 109:180-190.

de Lanerolle NC, Kim JH, Robbins RJ, Spencer DD (1989) Hippocampal interneuron loss and plasticity in human temporal lobe epilepsy. Brain Res 495:387-395.

Doherty J, Dingledine R (2001) Reduced excitatory drive onto interneurons in the dentate gyrus after status epilepticus. J Neurosci 21:2048-2057.

Engel Jr J, Williamson PD, Wieser HG (1997) Mesial temporal lobe epilepsy. In: Epilepsy: a comprehensive textbook. (Engel Jr J, Pedley TA, eds) pp 2417-2426. Philadelphia: Lippincott-Raven.

Erlander MG, Tillakaratne NJK, Feldblum S, Patel N, Tobin AJ (1991) Two genes encode distinct glutamate decarboxylases. Neuron 7:91-100.

Esclapez M, Houser CR (1999) Up-regulation of GAD65 and GAD67 in remaining hippocampal GABA neurons in a model of temporal lobe epilepsy. J Comp Neurol 412:488-505.

Esclapez M, Hirsch JC, Ben-Ari Y, Bernard C (1999) Newly formed excitatory pathways provide a substrate for hyperexcitability in experimental temporal lobe epilepsy. J Comp Neurol 408:449-460.

Feldblum S, Ackermann RF, Tobin AJ (1990) Long-term increase of glutamate decarboxylase mRNA in a rat model of temporal lobe epilepsy. Neuron 5:361-371.

Franck JE, Pokorny J, Kunkel DD, Schwartzkroin PA (1995) Physiologic and morphologic characteristics of granule cell circuitry in human epileptic hippocampus. Epilepsia 36:543-558.

Gibbs III JW, Shumate MD, Coulter DA (1997) Differential epilepsyassociated alterations in postsynaptic $\mathrm{GABA}_{\mathrm{A}}$ receptor function in dentate granule and CA1 neurons. J Neurophysiol 77:1924-1938.

Gorter JA, van Vliet EA, Aronica E, Lopes da Silva FH (2001) Progression of spontaneous seizures after status epilepticus is associated with mossy fibre sprouting and extensive bilateral loss of hilar parvalbumin and somatostatin-immunoreactive neurons. Eur J Neurosci 13:657-669.

Haas KZ, Sperber EF, Moshé SL, Stanton PK (1996) Kainic acid-induced seizures enhance dentate gyrus inhibition by downregulation of $\mathrm{GABA}_{\mathrm{B}}$ receptors. J Neurosci 16:4250-4260.

Halasy K, Somogyi P (1993) Distribution of GABAergic synapses and their targets in the dentate gyrus of rat: a quantitative immunoelectron microscopic analysis. J Hirnforsch 34:299-308.

Hirsch JC, Agassandian C, Merchán-Pérez A, Ben-Ari Y, DeFelipe J, Esclapez M, Bernard C (1999) Deficit of quantal release of GABA in experimental models of temporal lobe epilepsy. Nat Neurosci 2:499-500.

Houser CR, Esclapez M (1996) Vulnerability and plasticity of the GABA system in the pilocarpine model of spontaneous recurrent seizures. Epilepsy Res 26:207-218.

Isokawa M (1996) Decrement of $\mathrm{GABA}_{\mathrm{A}}$ receptor-mediated inhibitory postsynaptic currents in dentate granule cells in epileptic hippocampus. J Neurophysiol 75:1901-1908.

Isokawa M, Levesque MF (1991) Increased NMDA responses and dendritic degeneration in human epileptic hippocampal neurons in slices. Neurosci Lett 132:212-216.

Isokawa-Akesson M, Wilson CE, Babb TL (1989) Inhibition in synchronously firing human hippocampal neurons. Epilepsy Res 3:236-247. 
Katona I, Acsády L, Freund TF (1999) Postsynaptic targets of somatostatinimmunoreactive interneurons in the rat hippocampus. Neuroscience $88: 37-55$.

Kosaka T, Katsumaru H, Hama K, Wu J-Y, Heizmann CW (1987) GABAergic neurons containing the $\mathrm{Ca}^{2+}$-binding protein parvalbumin in the rat hippocampus and dentate gyrus. Brain Res 419:119-130.

Kraushaar U, Jonas P (2000) Efficacy and stability of quantal GABA release at a hippocampal interneuron-principal neuron synapse. J Neurosci 20:5594-5607.

Leranth C, Malcolm AJ, Frotscher M (1990) Afferent and efferent synaptic connections of somatostatin-immunoreactive neurons in the rat fascia dentata. J Comp Neurol 295:111-122.

Li H, Prince DA (2002) Synaptic activity in chronically injured, epileptogenic sensory-motor neocortex. J Neurophysiol 88:2-12.

Lynch M, Sutula T (2000) Recurrent excitatory connectivity in the dentate gyrus of kindled and kainic acid-treated rats. J Neurophysiol 83:693-704.

Margerison JH, Corsellis JAN (1966) Epilepsy and the temporal lobes. A clinical, electroencephalographic and neuropathological study of the brain in epilepsy, with particular reference to the temporal lobes. Brain 89:499-530.

Masukawa LM, Wang H, O’Connor MJ, Uruno K (1996) Prolonged field potentials evoked by $1 \mathrm{~Hz}$ stimulation in the dentate gyrus of temporal lobe epileptic human brain slices. Brain Res 721:132-139.

Mathern GW, Babb TL, Pretorius JK, Leite JP (1995a) Reactive synaptogenesis and neuron densities for neuropeptide $\mathrm{Y}$, somatostatin, and glutamate decarboxylase immunoreactivity in the epileptogenic human fascia dentata. J Neurosci 15:3990-4004.

Mathern GW, Babb TL, Vickrey BG, Melendez M, Pretorius JK (1995b) The clinical-pathogenic mechanisms of hippocampal neuron loss and surgical outcomes in temporal lobe epilepsy. Brain 118:105-118.

Mathern GW, Bertram III EH, Babb TL, Pretorius JK, Kuhlman PA, Spradlin S, Mendoza D (1997) In contrast to kindled seizures, the frequency of spontaneous epilepsy in the limbic status model correlates with greater aberrant fascia dentata excitatory and inhibitory axon sprouting and increased staining for $N$-methyl-D-aspartate, AMPA and $\mathrm{GABA}_{\mathrm{A}}$ receptors. Neuroscience 77:1003-1019.

Mathern GW, Pretorius JK, Mendoza D, Lozada A, Kornblum HI (1998) Hippocampal AMPA and NMDA mRNA levels correlate with aberrant fascia dentata mossy fiber sprouting in the pilocarpine model of spontaneous limbic epilepsy. J Neurosci Res 54:734-753.

Mello LEA, Cavalheiro EA, Tan AM, Kupfer WR, Pretorius JK, Babb TL, Finch DM (1993) Circuit mechanisms of seizures in the pilocarpine model of chronic epilepsy: cell loss and mossy fiber sprouting. Epilepsia 34:985-995.

Miles R, Wong RKS (1987) Inhibitory control of local excitatory circuits in the guinea-pig hippocampus. J Physiol (Lond) 388:611-629.

Mody I, Heinemann U (1987) NMDA receptors of dentate gyrus granule cells participate in synaptic transmission following kindling. Nature 326:701-704

Molnár P, Nadler JV (1999) Mossy fiber-granule cell synapses in the normal and epileptic rat dentate gyrus studied with minimal laser photostimulation. J Neurophysiol 82:1883-1894

Molnár P, Nadler JV (2000) $\gamma$-Aminobutyrate, $\alpha$-carboxy-2-nitrobenzyl ester selectively blocks inhibitory synaptic transmission in rat dentate gyrus. Eur J Pharmacol 391:255-262.

Molnár P, Nadler JV (2001) Lack of effect of mossy fiber-released zinc on granule cell $\mathrm{GABA}_{\mathrm{A}}$ receptors in the pilocarpine model of epilepsy. J Neurophysiol 85:1932-1940.

Morin F, Beaulieu C, Lacaille J-C (1998) Cell-specific alterations in synaptic properties of hippocampal CA1 interneurons after kainate treatment. J Neurophysiol 80:2836-2847.

Nusser Z, Hájos N, Somogyi P, Mody I (1998) Increased number of synaptic $\mathrm{GABA}_{\mathrm{A}}$ receptors underlies potentiation at hippocampal inhibitory synapses. Nature 395:172-177.

Obenaus A, Esclapez M, Houser CR (1993) Loss of glutamate decarboxylase mRNA-containing neurons in the rat dentate gyrus following pilocarpine-induced seizures. J Neurosci 13:4470-4485.

Okazaki MM, Evenson DA, Nadler JV (1995) Hippocampal mossy fiber sprouting and synapse formation after status epilepticus in rats: visualization after retrograde transport of biocytin. J Comp Neurol 352:515-534.

Okazaki MM, Molnár P, Nadler JV (1999) Recurrent mossy fiber pathway in rat dentate gyrus: synaptic currents evoked in presence and absence of seizure-induced growth. J Neurophysiol 81:1645-1660.
Otis TS, De Koninck Y, Mody I (1994) Lasting potentiation of inhibition is associated with an increased number of $\gamma$-aminobutyric acid type A receptors activated during miniature inhibitory postsynaptic currents. Proc Natl Acad Sci USA 91:7698-7702.

Patrylo PR, Schweitzer JS, Dudek FE (1999) Abnormal responses to perforant path stimulation in the dentate gyrus of slices from rats with kainate-induced epilepsy and mossy fiber reorganization. Epilepsy Res 36:31-42.

Represa A, Jorquera I, Le Gal La Salle G, Ben-Ari Y (1993) Epilepsy induced collateral sprouting of hippocampal mossy fibers: does it induce the development of ectopic synapses with granule cell dendrites? Hippocampus 3:257-268.

Ribak CE, Tran PH, Spigelman I, Okazaki MM, Nadler JV (2000) Status epilepticus-induced hilar basal dendrites on rodent granule cells contribute to recurrent excitatory circuitry. J Comp Neurol 428:240-253.

Schwarzer C, Williamson JM, Lothman EW, VezzaniA, Sperk G (1995) Somatostatin, neuropeptide $\mathrm{Y}$, neurokinin $\mathrm{B}$ and cholecystokinin immunoreactivity in two chronic models of temporal lobe epilepsy. Neuroscience 69:831-845.

Scotti AL, Bollag O, Kalt G, Nitsch C (1997) Loss of perikaryal parvalbumin immunoreactivity from surviving GABAergic neurons in the CA1 field of epileptic gerbils. Hippocampus 7:524-535.

Shinoda H, Nadi NS, Schwartz JP (1991) Alterations in somatostatin and proenkephalin mRNA in response to a single amygdaloid stimulation vs. kindling. Mol Brain Res 11:221-226.

Simmons ML, Terman GW, Chavkin C (1997) Spontaneous excitatory currents and $\kappa$-opioid receptor inhibition in dentate gyrus are increased in the rat pilocarpine model of temporal lobe epilepsy. J Neurophysiol $78: 1860-1868$.

Sloviter RS (1991) Permanently altered hippocampal structure, excitability, and inhibition after experimental status epilepticus in the rat: the "dormant basket cell" hypothesis and its possible relevance to temporal lobe epilepsy. Hippocampus 1:41-66.

Soltesz I, Smetters DK, Mody I (1995) Tonic inhibition originates from synapses close to the soma. Neuron 14:1273-1283.

Spigelman I, Yan X-X, Obenaus A, Lee EY-S, Wasterlain CG, Ribak CE (1998) Dentate granule cells form novel basal dendrites in a rat model of temporal lobe epilepsy. Neuroscience 86:109-120.

Sutula T, Zhang P, Lynch M, Sayin U, Golarai G, Rod R (1998) Synaptic and axonal remodeling of mossy fibers in the hilus and supragranular region of the dentate gyrus in kainate-treated rats. J Comp Neurol 390:578-594.

Tuff LP, Racine RJ, Adamec R (1983) The effects of kindling on GABAmediated inhibition in the dentate gyrus of the rat. I. Paired-pulse depression. Brain Res 277:79-90.

Turski WA, Cavalheiro EA, Schwarz M, Czuczwar SJ, Kleinrok Z, Turski L (1983) Limbic seizures produced by pilocarpine in rats: behavioural, electroencephalographic and neuropathological study. Behav Brain Res 9:315-336.

Ulrich D, Huguenard JR (1996) GABA $_{\mathrm{B}}$ receptor-mediated responses in GABAergic projection neurons of rat nucleus reticularis thalami in vitro. J Physiol (Lond) 493:845-854.

Uruno K, O’Connor MJ, Masukawa LM (1995) Effects of bicuculline and baclofen on paired-pulse depression in the dentate gyrus of epileptic patients. Brain Res 695:163-172.

Wanscher B, Kragh J, Barry DI, Bolwig T, Zimmer J (1990) Increased somatostatin and enkephalin-like immunoreactivity in the rat hippocampus following hippocampal kindling. Neurosci Lett 188:33-36.

Wierenga CJ, Wadman WJ (1999) Miniature inhibitory postsynaptic currents in CA1 pyramidal neurons after kindling epileptogenesis. J Neurophysiol 82:1352-1362.

Williamson A, Spencer SS, Spencer DD (1995) Depth electrode studies and intracellular dentate granule cell recordings in temporal lobe epilepsy. Ann Neurol 38:778-787.

Williamson A, Patrylo PR, Spencer DD (1999) Decrease in inhibition in dentate granule cells from patients with temporal lobe epilepsy. Ann Neurol 45:92-99.

Wilson CL, Khan SU, Engel Jr J, Isokawa M, Babb TL, Behnke EJ (1998) Paired pulse suppression and facilitation in human epileptogenic hippocampal formation. Epilepsy Res 31:211-230.

Wittner L, Maglóczky Z, Borhegyi Z, Halász P, Tóth S, Erőss L, Szabó Z Freund TF (2001) Preservation of perisomatic inhibitory input of granule cells in the epileptic human dentate gyrus. Neuroscience 108:587-600.

Wuarin J-P, Dudek FE (2001) Excitatory synaptic input to granule cells increases with time after kainate treatment. J Neurophysiol 85:1067-1077. 